\title{
Diversity and distribution of azooxanthellate corals in the Colombian Caribbean
}

\author{
Nadiezhda Santodomingo • Javier Reyes • Paola Flórez • \\ Isabel Cristina Chacón-Gómez • Leen P. van Ofwegen • \\ Bert W. Hoeksema
}

Received: 29 May 2012 /Revised: 31 August 2012 / Accepted: 23 September 2012 /Published online: 23 October 2012

(C) The Author(s) 2012. This article is published with open access at Springerlink.com

\begin{abstract}
During the last decade, knowledge of azooxanthellate corals in the Colombian Caribbean has increased through exploration campaigns by the Marine and Coastal Research Institute (INVEMAR). The distribution of 142 species of corals, including hard corals (Scleractinia 64 species), black corals (Antipatharia 18 species), and soft corals (Octocorallia 60 species) is assessed. Statistical analyses were performed to examine the coral species distribution through a geographic gradient (210 stations in 8 sectors) and a bathymetric range (10-520 m depth). Four principal patterns were observed: (1) northeastern distribution (46 species), (2) southwestern distribution (11 species), (3) association with azooxanthellate coral bioherms (37 species), and (4) widespread (44 species). In addition, 4 species were only found around the San Andres Archipelago (insular pattern). Two main oceanographic factors were identified to play a role in the northeast versus southwest coral fauna separation, La Guajira upwelling system and the Magdalena River influx. These patterns appear to
\end{abstract}

Electronic supplementary material The online version of this article (doi:10.1007/s12526-012-0131-6) contains supplementary material, which is available to authorized users.

\section{N. Santodomingo}

Department of Earth Sciences, Natural History Museum,

Cromwell Road,

SW7 5BD London, UK

e-mail: nsantodomingo@gmail.com

J. Reyes · P. Flórez • I. C. Chacón-Gómez

Museo de Historia Natural Marina de Colombia,

Marine and Coastal Research Institute (INVEMAR),

Cerro Punta Betin,

Santa Marta, Colombia

N. Santodomingo $\cdot$ L. P. van Ofwegen $\cdot$ B. W. Hoeksema $(\bowtie)$ Department of Marine Zoology, Naturalis Biodiversity Center, P.O. Box 9517, 2300 Leiden, The Netherlands

e-mail: bert.hoeksema@naturalis.nl be depth-related, since the separation between northeast and southwest was mainly shown by the shallow-water coral fauna, whereas most of the deep-water corals ( $>200 \mathrm{~m}$ depth) were widely distributed along the Colombian Caribbean coastline. These data were also analyzed from a conservation perspective in order to propose new strategies for the protection of the Colombian Caribbean coral fauna.

Keywords Azooxanthellate corals · Colombian Caribbean · Diversity $\cdot$ Scleractinia $\cdot$ Octocorallia $\cdot$ Antipatharia

\section{Introduction}

In response to the worldwide decline in marine diversity (Gaston 2000; Pandolfi et al. 2005), a paradigm shift has occurred towards better and more precautionary conservation and management of marine resources (Ludwig et al. 1993; Dayton 1998). These conservation strategies are designed through ecological models (Gering et al. 2003) based on which species occur within a particular area and on what factors control their distribution (Friedlander et al. 2003). The accomplishment of this task receives special attention in Colombia, which is also recognized for its megadiverse terrestrial biota (Mittermeier et al. 1997). Owing to Colombia's position between the Atlantic and the Pacific, each with distinct geological, oceanographic and climatic features, it is one of the countries with the highest marine biological diversity in South America (Díaz and Acero 2003; Miloslavich et al. 2010). Although marine biodiversity research of Colombia has a short history, considerable knowledge has been gathered in the last 10 years, particularly with regard to species inventories and ecosystem characterizations (e.g., Campos et al. 2004; Reyes et al. 2005, 2010; Benavides et al. 2011).

During the last decades, the Colombian continental shelf has been explored through a few research expeditions. The 
most important ones are those made by the $\mathrm{R} / \mathrm{V}$ "Oregon" in the 1960s, the R/V "Pillsbury" in 1972, and the B/I "Ancón" in 1995. Consequently, INVEMAR carried out six "Macrofauna" cruises (1998-2002) on board of the B/I "Ancón" to fill the information gap concerning the Colombian soft bottom fauna between 10 and $520 \mathrm{~m}$ depth (Saavedra-Díaz et al. 2000; Lattig and Reyes 2001; Borrero-Pérez et al. 2002a, b; Cruz et al. 2002; Gracia et al. 2002, 2004; Reyes and Santodomingo 2002; Roa-Varón et al. 2003; Borrero-Pérez and Benavides-Serrato 2004; Campos et al. 2004; Flórez-Romero et al. 2007). The discovery of azooxanthellate coral communities (Santodomingo et al. 2007) and methane seep ecosystems (Gracia et al. 2012) were among the most interesting results of these expeditions.

Earlier research on scleractinian azooxanthellate corals inhabiting Colombian shallow waters was carried out by von Prahl and Erhardt (1985, 1989), Werding and Sánchez (1989), Sánchez (1995), and Díaz et al. (2000), and regarding deep waters by Cairns $(1979,2000)$. The most representative studies on the taxonomy and ecology of Colombian octocorals were carried out by Botero (1987), Sánchez (1994, 1998, 1999, 2001), and Sánchez et al. (1997, 1998). Ecological and taxonomic research on antipatharians were performed by Sánchez (1999) and Opresko and Sánchez (1997, 2005). As a result of the recent marine macrofauna expeditions, knowledge about the Colombian coral fauna showed an important growth with three new species for science (Lattig and Cairns 2000; Reyes et al. 2009) and new records for the region (Reyes 2000; Lattig and Reyes 2001; Reyes et al. 2005; Chacón-Gómez et al. 2008, 2010, 2012).

Most results of these expeditions have only been presented in technical reports with no attempt to understand species distribution patterns. Therefore, the main goal of the present study is to analyze and compare the spatial distributions of Colombian Caribbean azooxanthellate anthozoans (orders Scleractinia, Alcyonacea, Pennatulacea, and Antipatharia) along a geographical gradient (210 stations in eight sectors) and a bathymetric range (10-520 m).

\section{Materials and methods}

Specimens were collected during the INVEMAR expeditions Macrofauna I (1999), Macrofauna II (2000), Uraba (2003), Corpoguajira (2005), and Marcoral (2005) on board of B/I "Ancón" using an epibenthic trawl net $(9 \times 1 \mathrm{~m}$ opening; 3 knots by $10 \mathrm{~min})$, a Van Veen grab $\left(601,0.03 \mathrm{~m}^{2}\right)$, and a heavy chained rocky dredge $(1 \times 0.4 \mathrm{~m}$ opening; 1.5 knots by $5 \mathrm{~min}$ ). Specimens collected during previous biodiversity projects and material donated to INVEMAR by the Smithonian Institution's National Museum of Natural History at Washington, DC (NMNH-SI) were also included in the analysis (specimens from San Andres and three stations at depths beyond $520 \mathrm{~m}$ ). In this way, the study comprised 210 sampling localities primarily covering a depth range from 10 to $520 \mathrm{~m}$ depth in the Colombian Caribbean (Table 1; Fig. 1a; ESM 2 Table S1).

Corals with polyps (in 70 or $96 \%$ ethanol) and dry coral skeletons were kept in the collection of the Museo de Historia Natural Marina de Colombia (MHNMC). Specimens were identified to species or to genus level in the case of some octocorals and antipatharians. Some identifications were confirmed by comparison with type material deposited in the NMNH-SI. Identifications were based on: Scleractinia (Cairns 1979, 2000; Zibrowius 1980); Octocorallia (Deichman 1936; Bayer 1961; Bayer et al. 1983; Verseveldt and Bayer 1988; Williams 1995, 1999; Sánchez and Wirshing 2005); and Antipatharia (Brook 1889; Opresko 2001, 2002, 2003, 2004, 2006; Opresko and Sánchez 2005). The database comprised a total of 1,226 records (online at http://siam.invemar.org.co/ siam/sibm/index.htm, accessed 30 October 2011).

Systematic surveys carried out by INVEMAR since 1999 along the Colombian Caribbean comprised eight sectors or seascapes (INVEMAR 2000; Díaz and Acero 2003), which are based on the topography and width of the continental shelf, the geomorphology of the coastal zone, upwelling, terrestrial run-off through major river outlets, and the distribution of the main marine ecosystems. These eight sectors are: La Guajira (GUA), Palomino (PAL), Tayrona (TAY), Magdalena (MAG), Coralline Archipelagos (ARCO), Gulf of Morrosquillo (MOR), Southern Colombian Caribbean (DAR), and San Andres and Old Providence islands (SAN). Bathymetric ranges include samples taken at 20,70, 150, 200, 300 , and $500 \mathrm{~m}$ depth. Therefore, the data was summarized in a matrix of presence/absence records of species in each sector of the Colombian Caribbean with their respective bathymetric ranges (Appendix 1). Sectors and depth ranges ( $>2$ species) were grouped using group-average clustering based on BrayCurtis similarities calculated on presence/absence of coral

Table 1 Number of sampling stations of various projects carried out in the Colombian Caribbean

\begin{tabular}{lll}
\hline Project & Localities & Methods \\
\hline Macrofauna I (1) & 61 & $\mathrm{~T}$ \\
Macrofauna II (1) & 74 & $\mathrm{~T}$ \\
Uraba 2003 (1) & 9 & $\mathrm{~T}$ \\
Corpoguajira (1) & 31 & $\mathrm{~T}$ \\
Marcoral (1) & 9 & $\mathrm{~T}, \mathrm{G}, \mathrm{D}$ \\
Biodiversity & 15 & $\mathrm{~S}$ \\
NMNH-SI (2,3) & 11 & $\mathrm{G}, \mathrm{D}$ \\
Total & 210 & \\
\hline
\end{tabular}

Research vessels: 1 B/I “Ancón”, 2 R/V "Pillsbury", 3 R/V “Oregon” Methods: $T$ trawling net, $G$ van Veen grab, $D$ rock dredge, $S$ scuba diving 
a

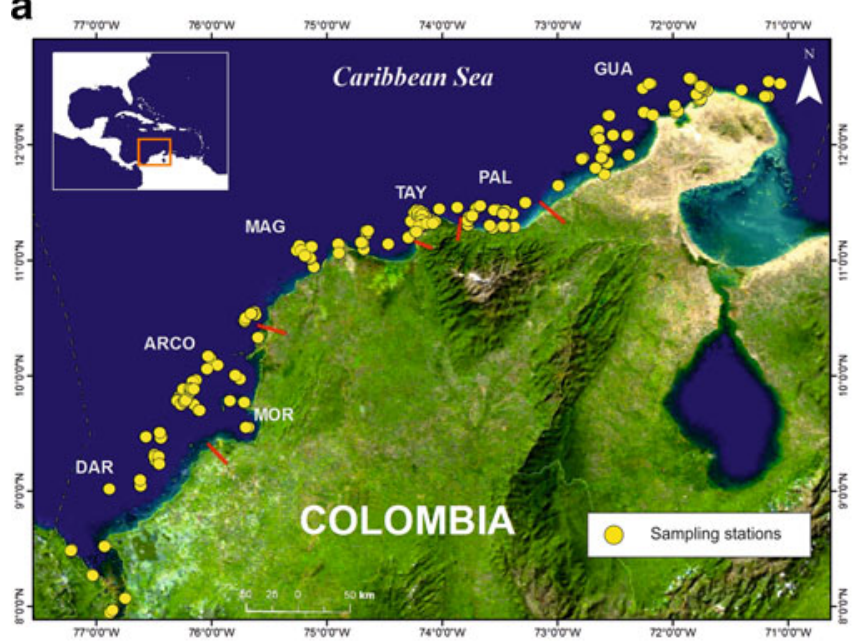

C

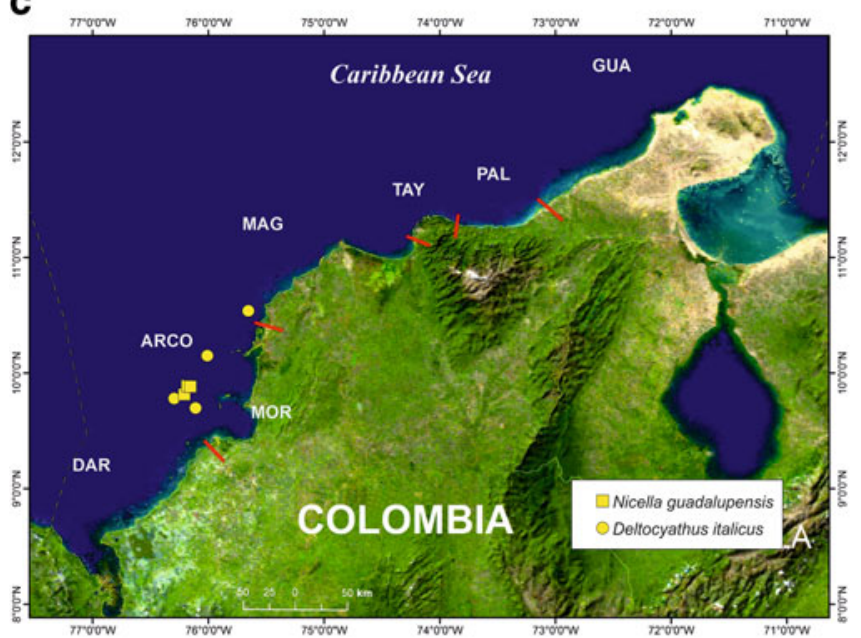

e

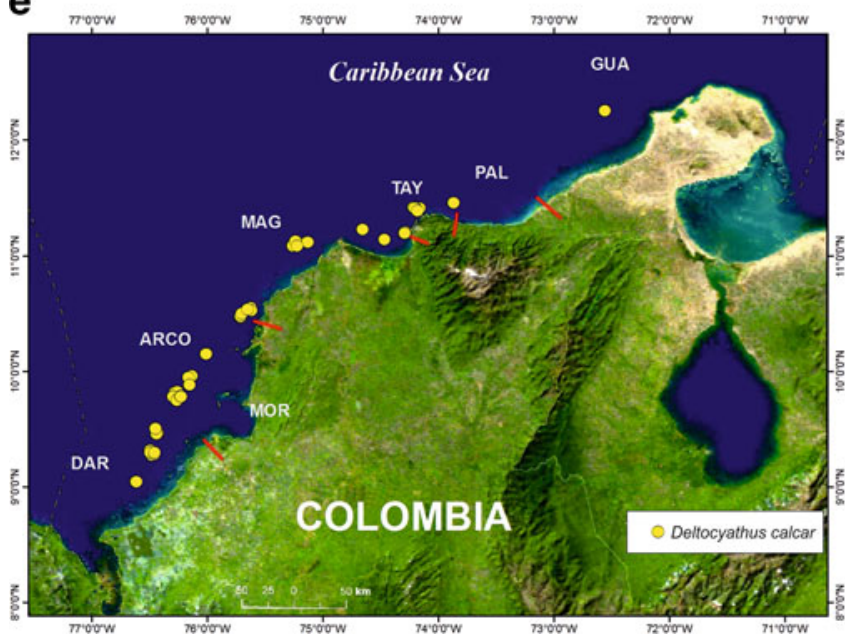

Fig. 1 a Distribution of sampling stations in the Colombian Caribbean in the sectors (red bars) La Guajira (GUA), Palomino (PAL), Tayrona (TAY), Magdalena $(M A G)$, Coralline Archipelagos (ARCO), Gulf of Morrosquillo $(M O R)$, and Southern Colombian Caribbean $(D A R)$. b-f Example maps of distribution patterns for azooxanthellate corals: $\mathbf{b}$ northeastern distribution of the octocoral Bellonella rubistella (family Alcyoniidae); c southwestern distributions of the octocoral Nicella guadalupensis (family Ellisellidae) and the free-living scleractinian Deltocyathus cf. italicus

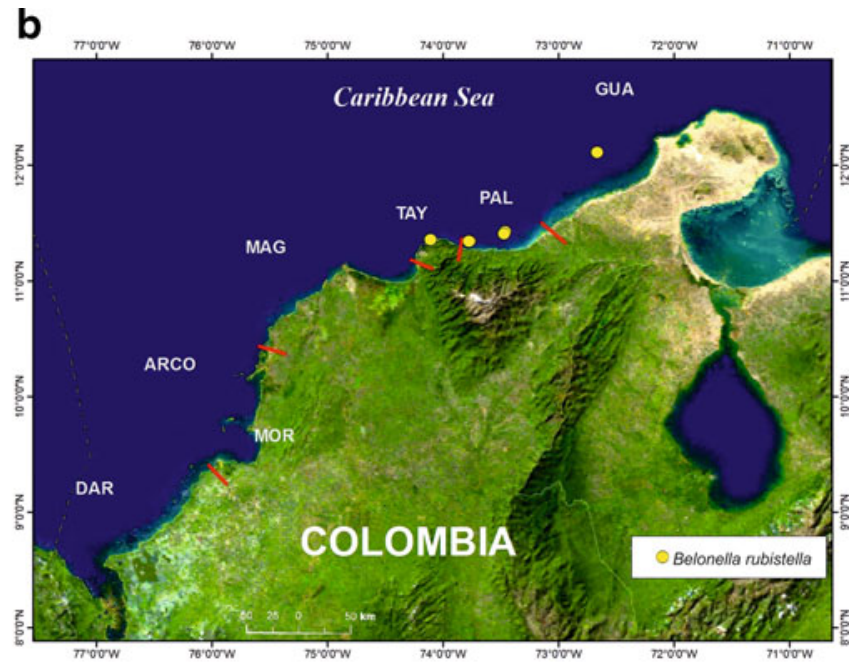

d

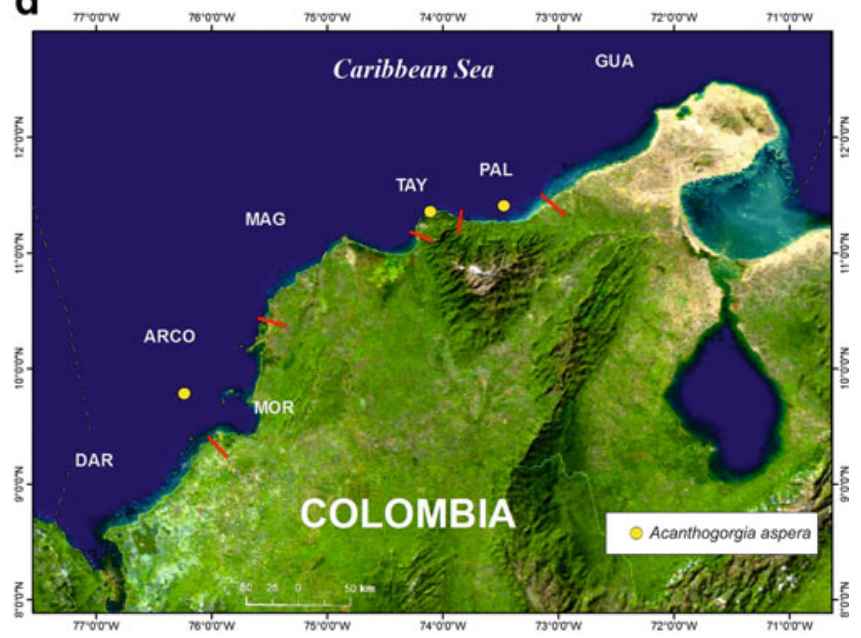

f

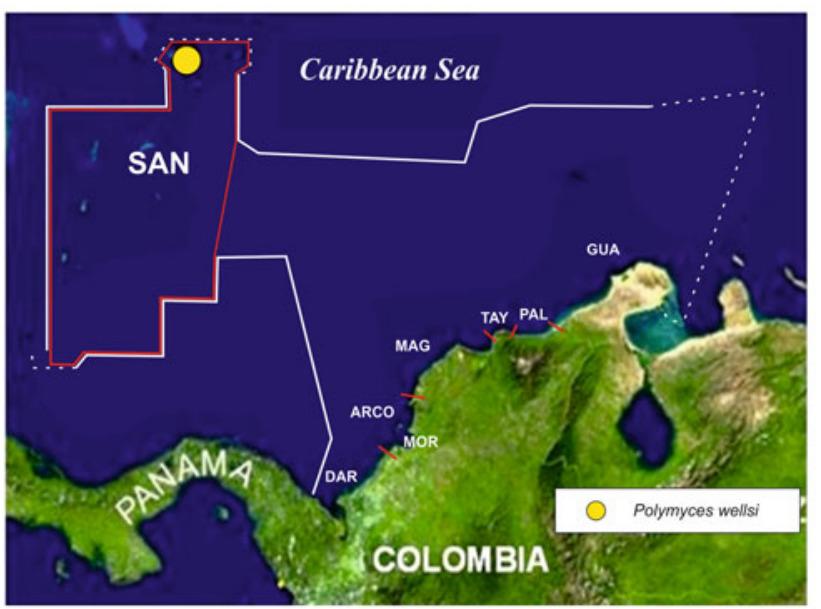

(family Caryophylliidae); $\mathbf{d}$ associated to coral bioherms: distribution of the octocoral Acanthogorgia aspera (family Acanthogorgiidae); e widespread: distribution of the hard coral Deltocyathus calcar (family Caryophylliidae); f insular pattern: distribution of the solitary scleractinian Polymyces wellsi (family Flabellidae), from the additional material collected in the sector San Andres and Providencia Archipelago (SAN) shown in red box; white line indicates the Colombian Economic Exclusive Zone (dotted line, borders in dispute) 
species data using PRIMER 6 software (Clarke and Gorley 2006). This information was sorted using non-metric multidimensional scaling (MDS). The MDS analysis was performed 100 times. Distribution maps of selected species were obtained after the incorporation of the dataset in a georeferenced matrix with ArcGISTM v.9.3 software.

\section{Results}

A total of 142 species was listed (Appendix 1), consisting of 64 Scleractinia (hard corals), 55 Alcyonacea (soft corals and gorgonians), 5 Pennatulacea (sea pens), and 18 Antipatharia (black corals). Over $50 \%$ of the scleractinians belonged to the Caryophylliidae ( $n=34$; ESM 1 Figs. S1-S3), which were followed by the Dendrophylliidae $(n=11$; Fig. S4), the Flabellidae ( $n=4)$, and the Pocilloporidae ( $n=4 ;$ Fig. S5), the Oculinidae ( $n=3$; Fig. S5), the Fungiacyathidae $(n=2)$, and the Turbinoliidae $(n=2)$, and the Gardineriidae, Guyniidae, Rhizangiidae, and Schizocyathidae, each with only 1 species (Fig. S5). Except for Cladocora arbuscula, all observed scleractinians were non-symbiotic (azooxanthellate) or facultative symbiotic (apozooxanthellate, see "*” in Appendix 1) (Cairns et al. 1999; Cairns and Kitahara 2012). The antipatharians were represented by 18 species belonging to four families (ESM 1 Fig. S6).

Octocorals (soft corals, gorgonians and sea pens) were represented by 60 species (ESM 1 Figs. S7-S12). The order Alcyonacea was represented by 55 species, belonging to 12 families: Plexauridae ( $n=19$; Fig. S12), Gorgoniidae $(n=8$; Fig. S10), Ellisellidae ( $n=7$; Fig. S9), Nidaliidae $(n=6$; Fig. S11), Chrysogorgiidae ( $n=5$; Fig. S8), Acanthogorgiidae $(n=4$; Fig. S7), and the Alcyoniidae, Anthothellidae, Clavularidae, Nephtheidae, Keroeididae and Primnoidae, each with only 1 species. The order Pennatulacea was represented by 5 species, which belong to three families (Fig. S13). Among the observed alcyonaceans, Muricea elongata, Pterogorgia sp. and Eunicea sp. are recognized as zooxanthellate ("+" in Appendix 1), 9 other species are apozooxanthellate ("**" in Appendix 1), while the remaining 43 species were azooxanthellate (Sánchez and Wirshing 2005).

Bathymetric distribution

The species richness varied along the depth range, reaching a peak of 86 species at the 100-200 m depth range (Fig. 2). The diversity distribution over depth intervals is symmetrical, exhibiting a lower number of species at the shallowest areas $(<50 \mathrm{~m})$ and deepest bottoms $(>200 \mathrm{~m})$. However, it is important to mention that our knowledge on azooxanthellate corals of the Colombian Caribbean can only be considered as comprehensive down to the $500 \mathrm{~m}$ depth, because only a few localities have been sampled below this isobath (Fig. 2, ESM 2 Table S1).
Geographic distribution

A maximum number of 76 species per sector was observed in Tayrona (Fig. 3), 17 of which were only found in this area (Appendix 1). Coralline archipelagos $(n=72)$ were ranked second in species richness. La Guajira $(n=62)$ and Palomino $(n=61)$ showed almost similarly high species numbers, whereas Magdalena $(n=21)$ and Darien $(n=19)$ scored much lower. The lowest diversity was observed in the Gulf of Morrosquillo sector with only 4 species of hard corals, and a total absence of octocorals and black corals (Fig. 3). Although no systematic surveys have been performed by INVEMAR in the sector of San Andres and Old Providence islands $(n=8)$, data retrieved from previous expeditions illustrate the lack of knowledge of this area and the need of filling in this gap.

\section{Distribution patterns}

Our statistical approach clustered the coral fauna into two main groups: (1) coral communities from deep bottoms $(>200 \mathrm{~m}$ ) on the continental slope and (2) coral communities on the continental shelf $\leq 200 \mathrm{~m}$ (Fig. 4a). Within the shallow fauna group, three main clusters were observed: (2a) southwestern, conformed by stations $<200 \mathrm{~m}$ from sectors MAG, ARCO, and DAR; (2b) northeastern, all the stations $<150 \mathrm{~m}$ from sectors GUA, PAL and TAY; and (2c) coral fauna associated to the bioherms represented by stations ARCO_150 and TAY_200. Exceptionally, the third azooxanthellate coral bioherm located in the Palomino sector (PAL_70) was more similar to the surrounding shallow-water fauna at the northeastern bioherm than to the other two. These four major groups were also observed in the MDS analysis (Fig. 4b). Based on these clusters, four principal distributional patterns of coral species in the Colombian Caribbean are proposed:

1. Northeast: 46 coral species (32\%) with occurrences at sectors GUA/PAL/TAY, mainly in shallow waters (32 species). Carijoa riisei (Fig. S9b), Renilla muelleri (Fig. S14a-g), and Stichopathes sp., which exhibited a GUA/PAL/TAY/MAG distribution, were also included in this category since their records were restricted to a single station at the north of the Magdalena River mouth. The distribution of the soft coral Bellonella rubistella is shown as an example (Figs. 1b, 5a).

2. Southwest: 11 species (8\%) distributed over sectors MAG/ARCO/DAR. Six species inhabit shallow waters (e.g., Nidalia occidentalis, Fig. S11f), while the other five occurred mainly in deep waters (e.g., Stephanocyathus diadema Fig. S3a, b). The distributions of Deltocyathus cf. italicus and Nicella guadalupensis are shown as examples (Figs. 1c, 5b).

3. Azooxanthellate coral bioherms: 37 coral species $(26 \%)$ exclusively living in azooxanthellate coral bioherms 


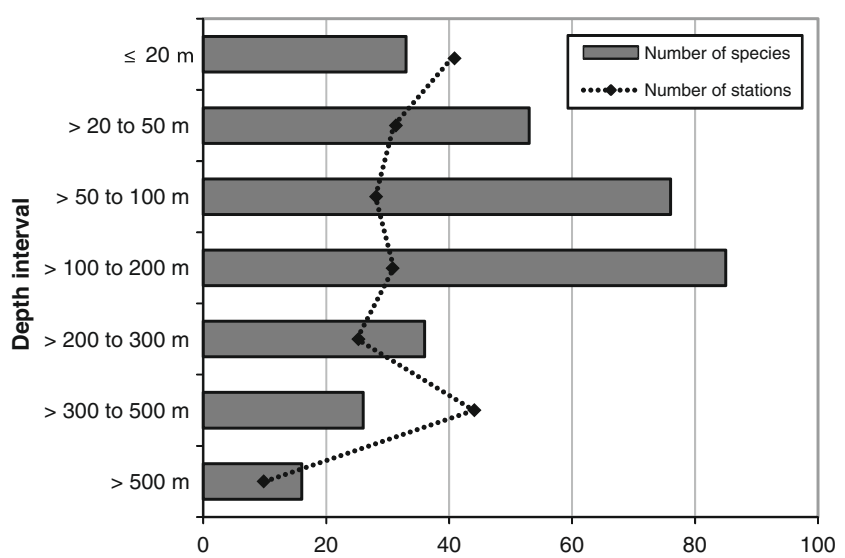

Fig. 2 Species richness distribution of azooxanthellate corals in the Colombian Caribbean over depth intervals. The number of stations sampled (diamonds) per depth interval is also indicated

(Reyes et al. 2005; Santodomingo et al. 2007). These bioherms are mainly constructed by Madracis asperula (Fig. S5t), M. myriaster (Fig. S5u), Anomocora fecunda (Fig. S1a, b), Cladocora debilis (Fig. S1n), and/or Eguchipsammia cornucopia (Fig. S4o), and were found in sectors Tayrona $(150 \mathrm{~m})$, Coralline Archipelagos $(200 \mathrm{~m})$, and Palomino $(70 \mathrm{~m})$. Examples of this distribution are the octocorals Acanthogorgia aspera (Figs. 1d, $5 \mathrm{c}$ ) and Stereonephthya portoricensis (Fig. S11b, c), the solitary scleractinian Coenocyathus parvulus (Fig. S1o, p), and the antipatharian Tanacetipathes barbadensis.

4. Widespread: 44 species (31\%), 10 of which are mainly from deep water (e.g., Stephanocyathus paliferus, Schizocyathus fissilis), 24 mainly from shallow-water (e.g., Diodogorgia nodulifera, Fig. S9a, and Trichogorgia lyra, Fig. S10e), while the other 10 species occur in both depth ranges (e.g., Caryophyllia berteriana, Fig. S1k, 1,

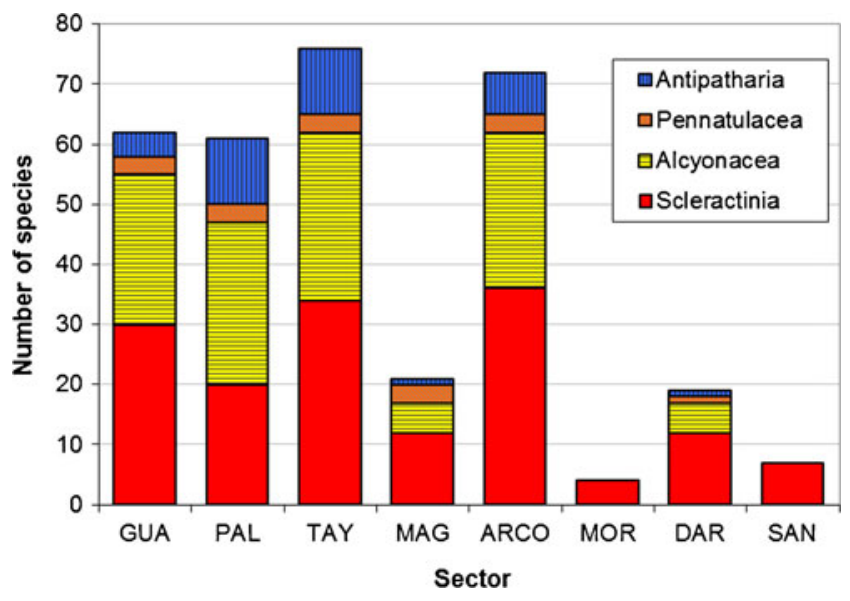

Fig. 3 Number of azooxanthellate species of Scleractinia, Alcyonacea, Pennatulacea, and Antipatharia in eight sectors of the Colombian Caribbean: La Guajira (GUA), Palomino (PAL), Tayrona (TAY), Coralline Archipelagos $(A R C O)$, Gulf of Morrosquillo $(M O R)$, Darien $(D A R)$, and San Andres and Old Providence islands $(S A N)$
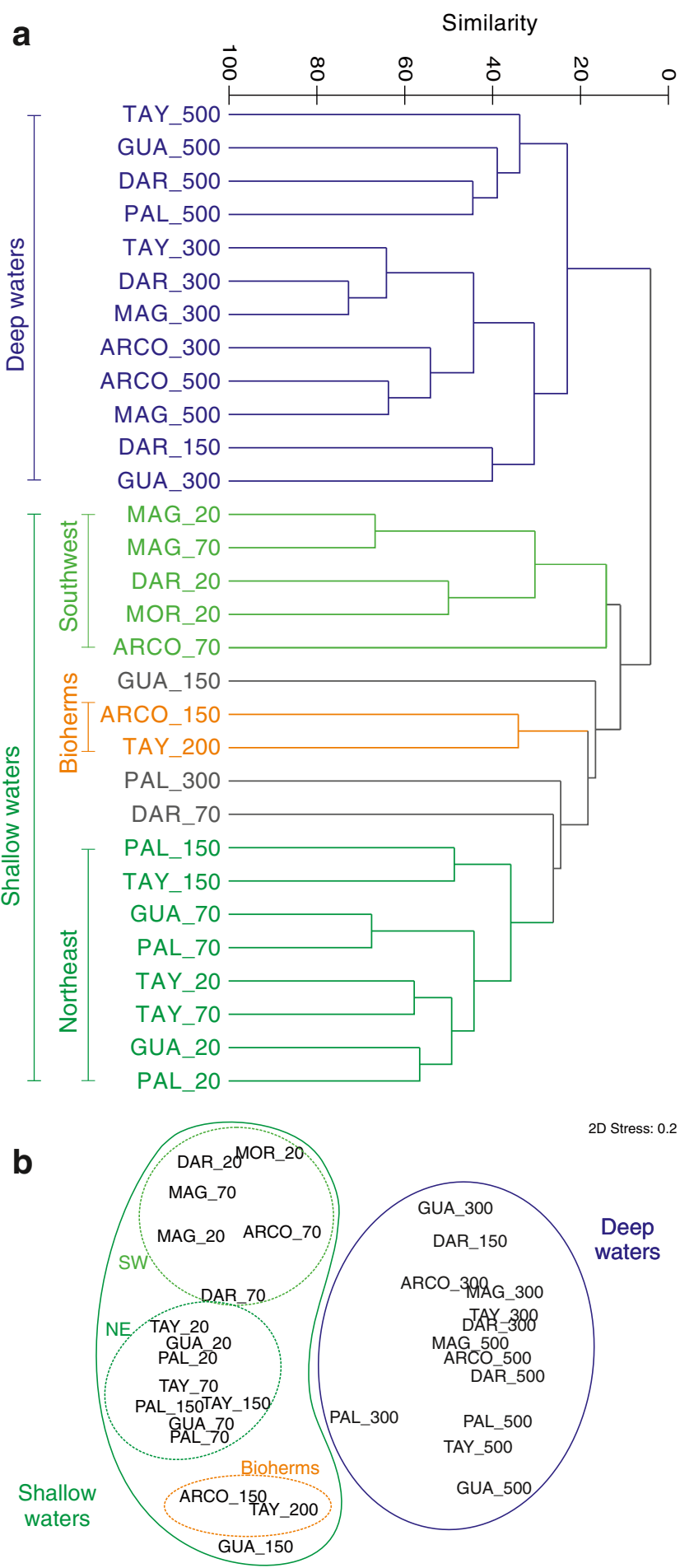

Fig. 4 a Bray-Curtis similarity analysis for the Colombian Caribbean sectors based on presence/absence of azooxanthellate corals; $\mathbf{b}$ MDS analysis based on presence/absence of azooxanthellate corals in the Colombian Caribbean. Codes for sectors were simplified to La Guajira $(G U A)$, Palomino (PAL), Tayrona (TAY), Coralline Archipelagos $(A R C O)$, and Darien $(D A R)$. Depth is indicated besides the sector code, e.g. Palomino at $500 \mathrm{~m}=$ PAL_500

and Oxysmilia rotundifolia, Fig. S2j, k). Deltocyathus calcar was the most widely distributed species (Figs. 1e, 


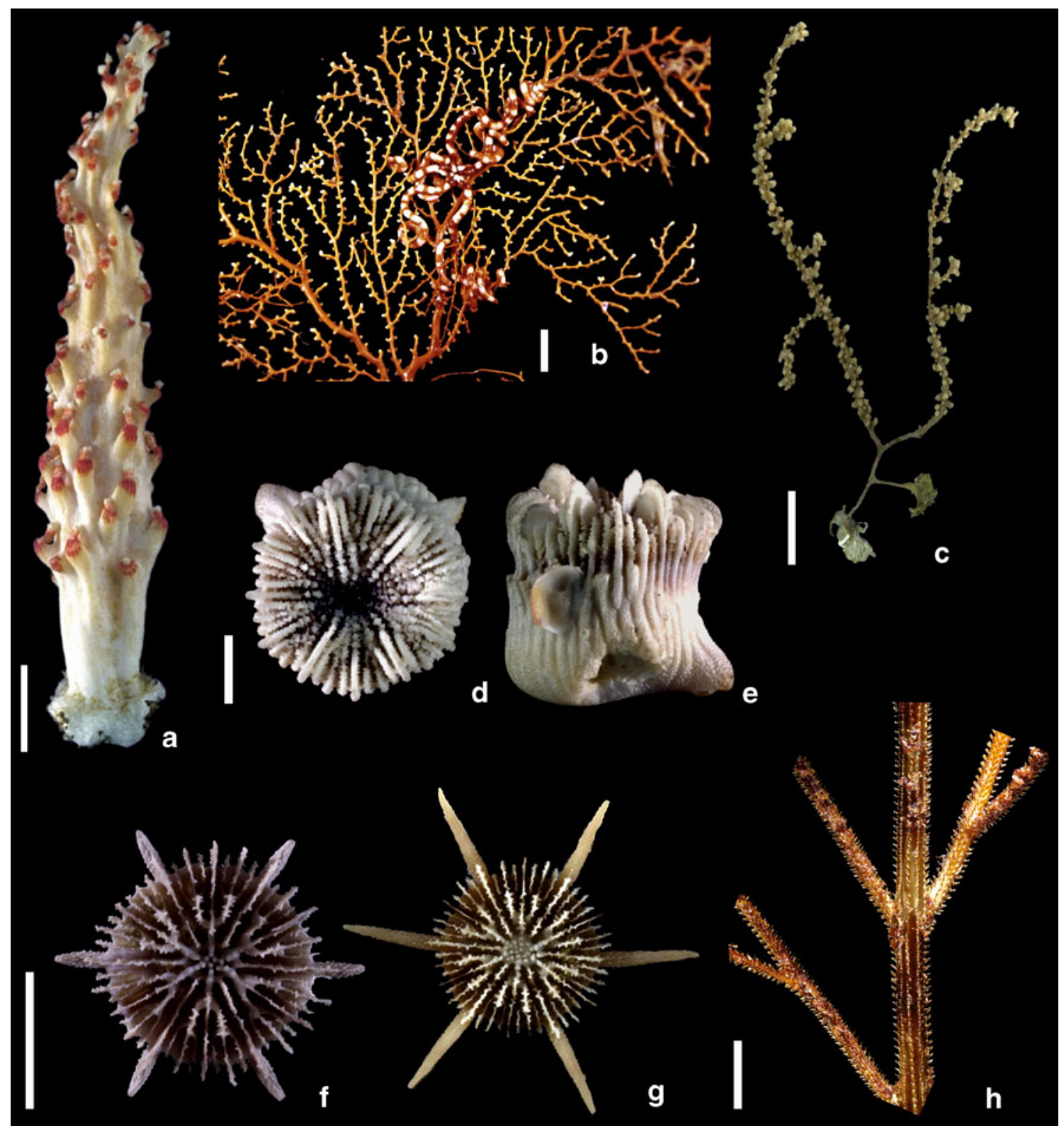

Fig. 5 Diversity of azooxanthellate corals of the Colombian Caribbean. Octocorals: a Bellonella rubistella, b Nicella guadalupensis, and c Acanthogorgia aspera. Scleractinians: d, e the endemic species
Heterocyathus antoniae, and $\mathbf{f}, \mathbf{g}$ morphological variability of Deltocyathus calcar. Antipatharian: h Aphanipathes salix. Scales $(\mathbf{a}-\mathbf{c})$ $1 \mathrm{~cm},(\mathbf{d}-\mathbf{g}) 5 \mathrm{~mm}$, (h) $2 \mathrm{~mm}$. More illustrations in ESM 1 5f-g), followed by Caryophyllia ambrosia caribbeana (Figs. S1g, h), and Deltocyathus eccentricus (Fig. S2c, d).

Despite a lack of systematic sampling around San Andres and Old Providence Archipelago, four of the eight species from here represent a distribution restricted to these islands: i.e. Stephanocyathus (Odontocyathus) coronatus (Fig. S3g, h), Balanophyllia hadros, Polymyces wellsi (Figs. 1f, S5g, h), and Fungiacyathus symmetricus (Fig. S5k). These islands consist of oceanic atolls that are located near Jamaica.
Endemism and similarities with the Pacific fauna

Heterocyathus antoniae (Fig. 5d, e), the only Colombian Caribbean scleractinian endemic, has a northeastern distribution pattern. This species is remarkable since congeneric extant species were only known from the Pacific, mainly on sandy bottoms adjacent to coral reefs in the eastern Pacific and Indian oceans, from Mozambique to Japan (Hoeksema and Best 1991; Cairns and Zibrowius 1997; Zibrowius 1998; Cairns 1999) and the Gulf of California (Durham and Barnard 1952). The last occurrence of Heterocyathus 
in the Tethys Ocean is known from the Miocene (20-15 MYA, Burdigalian) based on fossils recovered in southwestern France (Stolarski et al. 2001).

Tethocyathus prahli represents an interesting case of shared biota with the Pacific. This scleractinian species is an exclusive trans-isthmic species that does not exhibit a cosmopolitan distribution. It has been found off the Magdalena River delta (Colombia), Cocos Island (Costa Rica), and the northern coast of the Colombian Pacific (Lattig and Cairns 2000; Reyes et al. 2009). Concerning octocorals, it is noteworthy that Muricella (ESM 1 Fig. S7c, d) and Astrogorgia (ESM 1 Fig. S12a, b) were hitherto only known from the Indo-Pacific. In addition, specimens of Verrucella and Ctenocella, known from Pacific shallow waters (Hoeksema and van Ofwegen 2008) and western Atlantic deep waters (Bayer and Grasshoff 1995), are reported here for the first time in southern Caribbean shallow waters. Detailed taxonomic revisions of these four genera and the subsequent description of potentially new Colombian species are still needed to address further discussion on the similarities and divergences between the Tropical Eastern Pacific and Caribbean fauna.

\section{Discussion}

Corals thrive in shallow waters, mainly on coral reefs, which harbor the highest diversity of species known in the marine realm (Veron 2000; Fabricius and Aldersdale 2001), especially in the center of maximum marine species richness, the so-called Coral Triangle (Hoeksema 2007). The construction of reef structures is assisted by the symbiotic relationship with zooxanthellae. However, almost $66 \%$ of the scleractinian coral species lack this symbiosis and are found deeper than $50 \mathrm{~m}$ (Cairns et al. 1999; Cairns 2007), some of which form reefs on cold and deep-sea bottoms (Roberts et al. 2006). Only a few zooxanthellate coral species can be found deeper than $50 \mathrm{~m}$ in tropical seas, on so-called mesophotic reefs (Bongaerts et al. 2010).

During the present study, a high diversity of exclusively azooxanthellate coral species (138 spp.) was found exploiting a wider range of marine habitats such as soft-bottoms, hard-grounds, and deep-sea coral bioherms, far beyond the boundaries of shallow coral reefs. Thus, a higher species richness of azooxanthellate scleractinian corals $(n=63)$ in contrast to their zooxanthellate reef-dwelling counterparts $(n=54)$ has been observed in the Colombian Caribbean (Díaz et al. 2000; Reyes 2000; Reyes et al. 2010). The difference in species richness is even more remarkable for the antipatharians, with almost twice $(n=18)$ the number for mesophotic and aphotic deep waters $(\leq 520 \mathrm{~m})$ in comparison with the 10 species previously known in shallow-water Colombian reefs (Sánchez 1999; Opresko and Sánchez
1997, 2005). Regarding octocorals, around 70 species were known from studies on reef communities, with about half of the species belonging to only four zooxanthellate genera Eunicea $(n=12)$, Pseudopterogorgia $(n=10)$, Plexaura $(n=$ 5), and Pseudoplexaura ( $n=5$ ) (Botero 1987; Sánchez 1994, 1998, 1999, 2001; Sánchez et al. 1997, 1998); although the number of azooxanthellate octocoral species is lower $(n=$ 57), it is remarkable that most of the 33 genera were represented by one or two species, and only a few genera by more than four (e.g. Chrysogorgia, Nidalia, and Leptogorgia).

\section{Diversity with depth}

Depth has been recognized as one of the major parameters controlling coral species distribution (Houston 1985; Adjeroud 1997; Dawson 2002). In this study, the coral fauna varies in the bathymetric gradient, showing the lowest diversities in the shallowest and deepest bottoms, and a peak of high diversity at 100 to $200 \mathrm{~m}$ depth (Fig. 2). This pattern resembles those observed in other biogeographic provinces, where high species richness occurs on the border of continental margins between 100 and $300 \mathrm{~m}$ depth, as for example in azooxanthellate scleractinians of the Indo-Pacific (Cairns and Zibrowius 1997) and Brazil (Kitahara 2007), and octocorals of Japan (Matsumoto et al. 2007). The bathymetric pattern of Colombian azooxanthellate corals is also similar to that exhibited by azooxanthellate scleractinians at a global scale, which shows a high species richness at 50 $200 \mathrm{~m}$ depth (Cairns 2007). Despite the global diversity peak for this group at 200-1,000 m depth (Cairns 2007), more surveys would be required to attempt direct comparisons of our data with those ranges, as faunas $>500 \mathrm{~m}$ are still poorly sampled (Fig. 2).

Light is not a determinant factor in the distribution of azooxanthellate corals, whereas changes in salinity, temperature, nutrients, and sediments across the depth gradient can play a significant role in the presence and richness of species (Reyes-Bonilla and Cruz-Piñón 2000; Kitahara 2007). Oceanographic data reported for the Colombian Caribbean indicate that at 100-200 m depth, where the highest coral diversity is observed (61\%), the salinity is around $36.5 \mathrm{psu}$ and temperatures oscillate between 18 and $21{ }^{\circ} \mathrm{C}$ (Andrade and Barton 2000, 2005; Andrade et al. 2003).

Some studies have suggested that seawater calcium carbonate could play a major role in the biogeography of corals, as scleractinians deposit aragonite to build their skeletons and octocorals use calcite to form their sclerites (Buddemeier and Fautin 1996; Buddemeier and Smith 1999). Although this hypothesis is supported by a major development of speciesrich coral reefs in saturated waters above the aragonite saturation horizon (Guinotte et al. 2006; Cairns 2007), some corals with unique microstructural adaptations can live below carbonate saturation levels, such as micrabaciids, up to $5,000 \mathrm{~m}$ 
depth (Janiszewska et al. 2011) and Fungiacyathus, up to 6,000 m (Cairns 2007). So far, all Colombian corals have been surveyed above the aragonite saturation horizon, including records for Fungiacyathus crispus (up to $318 \mathrm{~m}$ ) and $F$. symmetricus (up to $842 \mathrm{~m}$ ). There are no records for micrabaciid corals, and Stephanocyathus diadema, the deepest-living coral (up to $1,257 \mathrm{~m}$ ) in this area.

The distinction between shallow and deep waters is arbitrary and its extent depends on the scope of each study. According to Cairns (2007), deep-water species are those occurring $>50 \mathrm{~m}$ depth based on the argument that few zooxanthellate coral species are present below this depth (but see Kahng and Maragos 2006; Bongaerts et al. 2010; Kahng et al. 2010). This limit was supported by Lindner et al. (2008) arguing that a 50-m wave disturbance boundary is used to determine the division between 'onshore' and 'offshore' environments in the fossil record (Bottjer and Jablonski 1988), and this corresponds approximately with the maximum depth at which regular storm-generated waves may cause sediment resuspension and disturbance to the benthos. In this study, a 200-m boundary was adopted to distinguish shallow- from deep-water, based on scleractinian studies by Cairns (1979, 2000) and because it corresponds with the continental shelf edge (Lakewood 1999; Stewart 2008). In this sense, the presence of an ecotone area with fauna elements of the continental shelf and the upper shelf slope may explain the maximum species diversity at 100-200 m depth.

\section{Biogeographic patterns}

The coral faunas of the northeastern (GUA, PAL, and TAY) and the southwestern (MAG, MOR, and DAR) sectors differ in terms of species richness and composition due to the synergy of two ecological factors. First, the cold-water upwelling off La Guajira increases the concentration of nutrients (Andrade et al. 2003; Andrade and Barton 2005) and therefore creates suitable conditions to the occurrence of suspension feeders such as corals. Second, the presence of the Magdalena River Delta and its freshwater and sediment discharge (Restrepo et al. 2006) could act as a barrier for the larval dispersion of coral species.

Coral fauna in shallow waters $(<200 \mathrm{~m})$ seem to follow this distribution pattern (northeastern vs. southeastern), while most of the deep-water species are widely distributed in the Colombian Caribbean. The relative constancy of deep-sea environmental conditions might explain the more homogeneous distribution of species in deep bottoms (Grassle 1991).

The diversity of scleractinian corals, solitary ones in particular, together with octocorals and antipatharians, was higher in areas where azooxanthellate coral bioherms occur (Roberts et al. 2006, 2009). This relationship is partly explained by the presence of hard-bottom substrates where solitary coral species and many other sessile suspension feeders live. It is evident that branching azooxanthellate corals (e.g., Madracis spp. Cladocora debilis, Thalamophyllia riisei, among others) are the principal components of such hard substrates as either living colonies or accumulated debris (Santodomingo et al. 2007).

It is remarkable that the Morrosquillo sector has only four species, including two common dwellers of artificial substrates, Phyllangia americana americana and Astrangia solitaria. This low diversity could be due to natural factors such as high sedimentation rates on shallow $(<40 \mathrm{~m})$ sea floors inside the Gulf of Morrosquillo, or to destructive fisheries, with the latter being the most plausible. The Gulf of Morrosquillo has been swept by shrimp trawling nets over more than 30 years. The primary gears have been trawling nets, both demersal and pelagic, that on average operate for about $9 \mathrm{~h}$ /day (Herazo et al. 2006). Octocorals are included in their bycatch (García et al. 2008). Consequently, it is possible that coral diversity and abundances were higher in the past. Unfortunately, there are no historical coral collections to support this hypothesis (see Hoeksema et al. 2011).

\section{Relationship with the Pacific fauna}

The closure of the Central American Isthmus (12-2.8 MYA) led to a great schism in the marine realm resulting in the extinction of some species and the development of two separate and distinctive marine faunas: the Tropical Eastern Atlantic from the Caribbean (Collins et al. 1996; Knowlton and Weigt 1998; Lessios 2008). Therefore, the occurrence of Tethocyathus prahli at both the Atlantic and Pacific Colombian coastal areas is remarkable (Lattig and Cairns 2000; Reyes et al. 2009) as a relict of the trans-isthmian fauna in deep waters and could be used in further phylogeographic studies.

The presence of a center of endemism in the Colombian Caribbean is suggested for the area surrounding La Aguja Canyon, located between sectors PAL and TAY. This hypothesis is based on the occurrence of the free-living coral Heterocyathus antoniae (Reyes et al. 2009), belonging to a genus previously only known from the Indo-Pacific (Hoeksema and Best 1991), as well as the fish Quadratus ancon (Mok et al. 2001), belonging to a West Pacific genus, and the ophiuroid Ophiosizygus disacanthus (Borrero-Pérez and Benavides-Serrato 2004), described from Japan. In addition, the particular distribution of these taxa suggests that they probably belong to an Atlantic relict fauna in this specific area of the Colombian Caribbean.

Colombian corals in the regional context

The geographic distribution patterns of azooxanthellate scleractinian corals described by Cairns $(1979,2000)$ based on geopolitical regions were successfully tested by using statistical analyses (see fig. 1 in Dawson 2002). However, 
those analyses were carried out on only the 42 Colombian azooxanthellate coral species known at that time. The recent addition of 17 new species records and 3 new species (Reyes 2000; Lattig and Reyes 2001; Reyes et al. 2005; Santodomingo et al. 2007) significatively increased the knowledge on azooxanthellate scleractinians in the Colombian Caribbean, which appears to have one of the most diverse coral faunas in the region with representatives of almost $50 \%$ of the described species in the western Atlantic region. Thus, although the patterns proposed by Cairns $(1979,2000)$ and Dawson (2002) explain general trends of scleractinian distribution in the Caribbean region, they do not resemble the patterns observed in the present study. Furthermore, distributions of octocorals and antipatharians are also included in the present analysis as an effort to cover the main groups of azooxanthellate anthozoans.

The current geographic distribution patterns revealed by Colombian azooxanthellate corals seem to correspond better with the delimitation of Marine Ecoregions of the World (MEOW) proposed by Spalding et al. (2007). In their proposal, the southern Caribbean MEOW (=northeastern Colombia) only includes La Guajira sector, while the remaining sectors, Palomino, Tayrona, Magdalena, Morrosquillo, Coralline Archipelagos and Darien, belong to the southwestern Caribbean MEOW (=southwestern Colombia). Based on the criteria used to define MEOWs as "areas of relatively homogeneous species composition, clearly distinct from adjacent systems" (Spalding et al. 2007), our results could contribute to a more precise delineation of MEOWs at the Colombian Caribbean. Consequently, a new proposal for the delimitation of MEOWs would include sectors under the influence of La Guajira upwelling system (La Guajira, Palomino and Tayrona sectors) within the southern Caribbean MEOW (=northeastern Colombia), and would include the remaining sectors (Magdalena, Morrosquillo, Coralline Archipelagos and Darien) within the southwestern Caribbean MEOW (=southwestern Colombia), also establishing the Magdalena River delta as a barrier.

Our comprehensive analysis highlights not only the importance of rigorous taxonomic studies but also indicates the need for more faunistic sampling in poorly studied areas in order to overcome Linnean and Wallacean shortfalls (Brown and Lomolino 1998; Lomolino 2004) and to better understand distribution patterns in the marine realm.

\section{Conservation topics}

Concerning the shallow-water coral reefs of Colombia, most reef areas have been included within Marine Protected Areas MPAs (Díaz et al. 2000), and the conservation status of nine coral species from Colombia was emphasized in the IUCN Red List of endangered species of Colombia (Ardila et al. 2002). The recent discovery of three azooxanthellate coral communities of the Colombian Caribbean and their high associated diversity of molluscs, crustaceans, echinoderms, bryozoans, and fishes (Reyes et al. 2005; Santodomingo et al. 2007) has promoted the inclusion of this ecosystem in the conservation priorities for the design and management of some MPAs (Alonso et al. 2008a, b). For instance, the establishment of the 200-m isobath border for the Rosario and San Bernardo Coralline Archipelagos MPA was supported by the presence of azooxanthellate Madracis coral bioherms between 150 and $160 \mathrm{~m}$ depth within its boundaries (MAVDT 2005). Although the second azooxanthellate coral bioherm is located in the area adjacent to the Tayrona National Park, the management plans of this MPA do not so far include this ecosystem. Moreover, the high coral diversity found in La Guajira and Palomino sectors could be affected by the current increment of trawling fishing registered in these sectors (Viaña et al. 2002). Some strategies have been designed for the future establishment of an MPA network in this area (Alonso et al. 2008b), including the Palomino sector, which contains the third azooxanthellate coral community.

The need for conservation of many reef coral species has been established because they are relatively well known and relatively few species are considered data-deficient (Carpenter et al. 2008). The present study indicates that information about the deep-water coral fauna is scarce. Future campaigns in areas with special biodiversity values, such as La Aguja Canyon in the Tayrona sector (down to $3,000 \mathrm{~m}$ depth) or around the Lophelia pertusa records of La Guajira (500-1,000 m), would not only provide important information to the knowledge of the Colombian coral fauna and its deep-water coral communities but also increase our knowledge on the global deep-water coral fauna, which may be important for its protection.

Acknowledgements Special thanks to S. Cairns for his advice, support, and allowing the use of the National Museum of Natural History coral collection. Thanks to D. Opresko (Oak Ridge National Laboratory) and G. Williams (California Academy of Science) for giving advice and literature for the identification of antipatharians and pennatulaceans, respectively. Thanks to J. Sánchez (Universidad de Los Andes) for fruitful discussions. Thanks to P. Lattig for her help on identifications. G. Navas, A. Gracia, L. S. Mejia, N. Ardila, G. Borrero, N. Cruz, M. Benavides, A. Polanco, A. Bermudez, A. Roa, M. Díaz, and E. Montoya participated in the expeditions (INVEMAR). T. López and B. Rodriguez provided some pictures of corals. S. Braden (Smithsonian Institution) helped during SEM sessions of Guyniidae and Pennatulacea specimens, and A. Freiwald facilitated the use of the SEM laboratory at the Institute of Palaeontology (ErlangenNuremberg University). J. Bohórquez, L. Arias and C. Garcia (LAB-SI, INVEMAR) facilitated the access to the marine biodiversity database. The study of deep-sea corals of the Colombian Caribbean was possible thanks to the financial and logistic support of INVEMAR and the Instituto Colombiano para el Desarrollo de la Ciencia y la Tecnología "Francisco José de Caldas (COLCIENCIAS) given to the projects Macrofauna I, Macrofauna II (2105-13-07997) and MARCORAL (2115-09-16649). The MSc study of NS was funded by the Alßan Programme (code E07M402757CO). The valuable comments of S.E.T. van der Meij and three anonymous reviewers helped to improve this manuscript.

Open Access This article is distributed under the terms of the Creative Commons Attribution Noncommercial License which permits any noncommercial use, distribution, and reproduction in any medium, provided the original author(s) and source are credited. 


\section{Appendix}

Table 2 Distribution of 142 species of azooxanthellate corals: 64 Scleractinia, 18 Antipatharia, 55 Alcylonacea, and 5 Pennatulacea collected during INVEMAR expeditions in the Colombian Caribbean. Sectors: La Guajira $(G U A)$, Palomino $(P A L)$, Tayrona (TAY), Coralline Archipelagos $(A R C O)$, Darien $(D A R)$ and San Andres and Old Providence islands $(S A N)$; exclusive species to one of the sectors $($ Ex. $=\bullet$ ). Geographical distribution pattern (GeoP): Widespread (Wide),
Northeast mainly in sectors GUA/PAL/TAY $(N E)$, Southwest mainly in sectors MAG/ARCO/DAR $(S W)$, associated to azooxanthellate coral bioherms present in the sectors PAL, TAY and ARCO (Bioherm), Insular (Is) and Endemic to the Colombian Caribbean (Endemic). Bathymetric range (BatR): (1) shallow waters, (2) shallow and deep waters, (3) deep waters. Most are azooxanthellate species (unmarked), except for $(+)$ zooxanthellate and $(*)$ apozooxanthellate

\begin{tabular}{|c|c|c|c|c|c|c|c|c|c|c|c|c|c|}
\hline Species & Code & GUA & PAL & TAY & MAG & $\mathrm{ARCO}$ & MOR & DAR & SAN & Ex. & GeoP & BatR & Depth \\
\hline \multicolumn{14}{|l|}{ Order Scleractinia } \\
\hline \multicolumn{14}{|l|}{ Family Caryophylliidae } \\
\hline Anomocora fecunda (Pourtalès, 1871) & Afec & GUA & PAL & TAY & - & $\mathrm{ARCO}$ & - & DAR & - & & Wide & 1 & $10-200 \mathrm{~m}$ \\
\hline Anomocora marchadi (Chevalier, 1966) & Amar & GUA & PAL & - & - & - & - & - & - & & $\mathrm{NE}$ & 1 & $50 \mathrm{~m}$ \\
\hline Anomocora prolifera (Pourtalès, 1871) & Apro & GUA & PAL & TAY & - & $\mathrm{ARCO}$ & - & - & - & & Wide & 1 & $50-200 \mathrm{~m}$ \\
\hline Caryophyllia ambrossia caribbeana Cairns, 1979 & Caca & - & PAL & TAY & MAG & $\mathrm{ARCO}$ & - & DAR & - & & Wide & 3 & $200-510 \mathrm{~m}$ \\
\hline Caryophyllia barbadensis Cairns, 1979 & Cbar & - & - & - & - & $\mathrm{ARCO}$ & - & - & - & • & Bioherm & 1 & $160 \mathrm{~m}$ \\
\hline Caryophyllia berteriana Duchassaing, 1850 & Cber & GUA & - & TAY & - & $\mathrm{ARCO}$ & - & - & SAN & & Wide & 2 & $22-293 \mathrm{~m}$ \\
\hline Caryophyllia crypta Cairns, 2000 & Cory & - & - & TAY & - & - & - & - & - & • & $\mathrm{NE}$ & 1 & $17 \mathrm{~m}$ \\
\hline Cladocora arbuscula (Lesueur, 1821) ${ }^{+}$ & Carb & GUA & PAL & TAY & - & - & - & - & - & & NE & 1 & $10-60 \mathrm{~m}$ \\
\hline Cladocora debilis Milne Edwards and Haime, 1849 & Cdeb & GUA & PAL & TAY & MAG & $\mathrm{ARCO}$ & - & - & - & & Wide & 1 & $10-153 \mathrm{~m}$ \\
\hline Coenocyathus parvulus (Cairns, 1979) & Cpar & - & PAL & - & - & $\mathrm{ARCO}$ & - & - & - & & Bioherm & 1 & $21-160 \mathrm{~m}$ \\
\hline Coenosmilia arbuscula Pourtalès, 1874 & Coar & - & - & TAY & - & $\mathrm{ARCO}$ & - & - & - & & Bioherm & 1 & $72-218 \mathrm{~m}$ \\
\hline Colangia immersa Pourtalès, 1871 & Cimm & GUA & - & - & - & - & - & - & - & • & NE & 1 & $73 \mathrm{~m}$ \\
\hline Deltocyathus calcar Pourtalès, 1874 & Dcal & GUA & PAL & TAY & MAG & $\mathrm{ARCO}$ & - & DAR & - & & Wide & $2(3)$ & $107-520 \mathrm{~m}$ \\
\hline Deltocyathus eccentricus Cairns, 1979 & Decc & GUA & - & TAY & MAG & $\mathrm{ARCO}$ & - & DAR & - & & Wide & 3 & $270-507 \mathrm{~m}$ \\
\hline Deltocyathus italicus (Michelotti, 1838) & Dita & - & - & - & MAG & $\mathrm{ARCO}$ & - & - & - & & SW & $2(3)$ & $70.9-500 \mathrm{~m}$ \\
\hline Heterocyathus antoniae Reyes, Santodomingo and Cairns, 2009 & Hant & - & PAL & TAY & - & - & - & - & - & & Endemic & 1 & $21-76 \mathrm{~m}$ \\
\hline Lophelia pertusa (Linnaeus, 1758) & Lper & GUA & - & - & - & - & - & - & - & • & $\mathrm{NE}$ & 3 & $305-314 \mathrm{~m}$ \\
\hline Oxysmilia rotundifolia (Milne Edwards and Haime, 1848) & Orot & - & - & TAY & - & $\mathrm{ARCO}$ & - & - & SAN & & Wide & 2 & $107-238 \mathrm{~m}$ \\
\hline Paracyathus pulchellus (Philippi, 1842) & Ppul & GUA & PAL & - & - & $\mathrm{ARCO}$ & - & - & - & & Wide & 2 & $10-269 \mathrm{~m}$ \\
\hline Phacelocyathus flos (Pourtalès, 1878) & Pflo & - & - & - & - & $\mathrm{ARCO}$ & - & - & - & & SW & 1 & $150-180 \mathrm{~m}$ \\
\hline Phyllangia americana (Milne Edwards and Haime, 1848) & Pame & GUA & PAL & TAY & - & - & MOR & DAR & - & & Wide & 1 & $10-73 \mathrm{~m}$ \\
\hline Polycyathus mayae Cairns, 2000 & Pmay & - & - & - & - & $\mathrm{ARCO}$ & - & - & - & • & Bioherm & 1 & $113-160 \mathrm{~m}$ \\
\hline Polycyathus senegalensis Chevalier, 1966 & Psen & GUA & - & - & - & - & - & - & - & • & $\mathrm{NE}$ & 1 & $73-152 \mathrm{~m}$ \\
\hline Rhizosmilia maculata (Pourtalès, 1874) & Rmac & - & - & TAY & - & - & - & - & - & • & $\mathrm{NE}$ & 1 & $15-42 \mathrm{~m}$ \\
\hline Stephanocyathus (S.) diadema (Moseley, 1876) & Sdia & - & - & - & MAG & ARCO & - & - & - & & SW & 3 & $502-1,257 \mathrm{~m}$ \\
\hline $\begin{array}{l}\text { Stephanocyathus (S.) isabellae Reyes, Santodomingo and Cairns } \\
2009\end{array}$ & Sisa & GUA & PAL & - & - & $\mathrm{ARCO}$ & - & - & - & & Wide & 3 & $493-504 \mathrm{~m}$ \\
\hline Stephanocyathus (S.) paliferus Cairns, 1977 & Spal & GUA & - & - & MAG & $\mathrm{ARCO}$ & - & DAR & - & & Wide & 3 & $269-510 \mathrm{~m}$ \\
\hline Stephanocyathus (S.) laevifundus Cairns, 1977 & Slae & - & - & - & - & - & - & DAR & - & • & SW & 3 & $\begin{array}{l}1,158- \\
1,225 \mathrm{~m}\end{array}$ \\
\hline Stephanocyathus $(O$.$) coronatus Cairns, 1977$ & Scor & - & - & - & - & - & - & - & SAN & - & Is & 3 & $750-768 \mathrm{~m}$ \\
\hline Tethocyathus prahli Lattig and Cairns, 2000 & Tprah & GUA & - & - & MAG & - & - & - & - & & Wide & 3 & $152-310 \mathrm{~m}$ \\
\hline Tethocyathus variabilis Cairns, 1979 & Tvar & - & - & - & - & $\mathrm{ARCO}$ & - & - & - & • & Bioherm & 1 & $113-160 \mathrm{~m}$ \\
\hline Thalamophyllia riisei (Duchassaing and Michelotti, 1864) & Trii & - & - & - & - & $\mathrm{ARCO}$ & MOR & - & SAN & & Wide & 1 & $22-160 \mathrm{~m}$ \\
\hline Trochocyathus cf. fasciatus Cairns, 1979 & Tfas & - & - & TAY & - & - & - & - & - & - & $\mathrm{NE}$ & 2 & $218 \mathrm{~m}$ \\
\hline Trochocyathus rawsonii Pourtalès, 1874 & Traw & GUA & PAL & - & - & $\mathrm{ARCO}$ & - & - & - & & Wide & 2 & $70-308 \mathrm{~m}$ \\
\hline \multicolumn{14}{|l|}{ Family Dendrophylliidae } \\
\hline Balanophyllia bayeri Cairns, 1979 & Bbay & - & - & TAY & - & - & - & - & - & • & Bioherm & 1 & $200 \mathrm{~m}$ \\
\hline Balanophyllia caribbeana Cairns, 1977 & Bcar & GUA & - & TAY & - & $\mathrm{ARCO}$ & - & - & - & & Wide & 1 & $20.4-107 \mathrm{~m}$ \\
\hline Balanophyllia cyathoides (Pourtalès, 1871) & Bcya & GUA & - & TAY & - & $\mathrm{ARCO}$ & - & - & - & & Wide & 1 & $70.5-200 \mathrm{~m}$ \\
\hline Balanophyllia dineta Cairns, 1977 & Bdin & GUA & - & - & - & - & - & - & - & • & $\mathrm{NE}$ & 1 & $151 \mathrm{~m}$ \\
\hline Balanophyllia hadros Cairns, 1979 & Bhad & - & - & - & - & - & - & - & SAN & - & Is & 3 & $238-247 \mathrm{~m}$ \\
\hline Balanophyllia palifera Pourtalès, 1878 & Bpal & GUA & - & TAY & - & $\mathrm{ARCO}$ & - & - & - & & Wide & 1 & $22-218 \mathrm{~m}$ \\
\hline Balanophyllia pittieri (Cairns, 1977) & Bpit & GUA & - & TAY & - & - & - & - & - & & $\mathrm{NE}$ & 1 & $70.1-200 \mathrm{~m}$ \\
\hline Balanophyllia wellsi Cairns, 1977 & Bwel & GUA & - & - & - & $\mathrm{ARCO}$ & - & - & - & & Wide & 1 & $73-160 \mathrm{~m}$ \\
\hline
\end{tabular}


Table 2 (continued)

\begin{tabular}{|c|c|c|c|c|c|c|c|c|c|c|c|c|c|}
\hline Species & Code & GUA & PAL & TAY & MAG & $\mathrm{ARCO}$ & MOR & DAR & SAN & Ex. & GeoP & BatR & Depth \\
\hline Eguchipsammia cornucopia Pourtalès, 1871 & Ecor & - & - & - & - & $\mathrm{ARCO}$ & - & - & - & • & Bioherm & 1 & $117-160 \mathrm{~m}$ \\
\hline Rhizopsammia goesi (Lindstroem, 1877) & Rgoe & GUA & - & - & - & - & - & - & - & $\cdot$ & NE & 1 & $73-152 \mathrm{~m}$ \\
\hline Tubastraea coccinea Lesson, 1829 & Tcoc & GUA & PAL & TAY & - & $\mathrm{ARCO}$ & - & - & - & & Wide & 1 & $10 \mathrm{~m}$ \\
\hline \multicolumn{14}{|l|}{ Family Flabellidae } \\
\hline Flabellum moseleyi Pourtalès, 1880 & Fmos & - & PAL & TAY & MAG & $\mathrm{ARCO}$ & - & DAR & - & & Wide & 3 & $304-520 \mathrm{~m}$ \\
\hline Javania cailleti (Duchassaing and Michelotti, 1864) & Jcai & GUA & - & TAY & - & $\mathrm{ARCO}$ & - & - & SAN & & Wide & 2 & $113-238 \mathrm{~m}$ \\
\hline Polymyces fragilis Pourtalès, 1868 & Pfrag & - & - & TAY & - & - & - & - & - & • & Bioherm & 2 & $200-218 \mathrm{~m}$ \\
\hline Polymyces wellsi Cairns, 1991 & Pwel & - & - & - & - & - & - & - & SAN & • & Is & 3 & $548 \mathrm{~m}$ \\
\hline \multicolumn{14}{|l|}{ Family Fungiacyathidae } \\
\hline Fungiacyathus crispus (Pourtalès, 1871) & Fcri & - & PAL & TAY & MAG & - & - & DAR & - & & Wide & 3 & $276-318 \mathrm{~m}$ \\
\hline Fungiacyathus symmetricus (Pourtalès, 1871) & Fsym & - & - & - & - & - & - & - & SAN & • & Is & 3 & $576-842 \mathrm{~m}$ \\
\hline \multicolumn{14}{|l|}{ Family Gardineriidae } \\
\hline Gardineria minor Wells, 1973 & Gmin & - & - & TAY & - & $\mathrm{ARCO}$ & - & - & - & & Bioherm & 1 & $17-107 \mathrm{~m}$ \\
\hline \multicolumn{14}{|l|}{ Family Guyniidae } \\
\hline Guynia annulata Duncan, 1872 & Gann & - & PAL & TAY & - & - & - & - & - & & NE & 1 & $150-153 \mathrm{~m}$ \\
\hline \multicolumn{14}{|l|}{ Family Oculinidae } \\
\hline Madrepora carolina (Pourtalès, 1871) & Mcar & - & - & - & - & $\mathrm{ARCO}$ & - & - & - & • & Bioherm & 1 & $108-155 \mathrm{~m}$ \\
\hline Madrepora oculata Linnaeus, 1758 & Mocu & - & - & - & - & $\mathrm{ARCO}$ & - & - & - & • & SW & 3 & $924-950 \mathrm{~m}$ \\
\hline Oculina tenella Pourtalès, 1871 & Oten & GUA & PAL & TAY & - & - & - & - & - & & NE & 1 & $21.4-150 \mathrm{~m}$ \\
\hline \multicolumn{14}{|l|}{ Family Pocilloporidae } \\
\hline Madracis asperula Milne Edwards and Haime, 1849 & Masp & GUA & PAL & - & - & $\mathrm{ARCO}$ & - & - & - & & Wide & 1 & $20-153 \mathrm{~m}$ \\
\hline Madracis brueggemanni (Ridley, 1881) & Mbru & - & - & - & - & $\mathrm{ARCO}$ & - & - & - & $\cdot$ & Bioherm & 1 & $107-160 \mathrm{~m}$ \\
\hline Madracis myriaster (Milne Edwards and Haime, 1849) & Mmyr & GUA & - & TAY & - & $\mathrm{ARCO}$ & MOR & DAR & - & & Wide & 2 & $21.4-300 \mathrm{~m}$ \\
\hline Madracis pharensis (Heller, 1868) & Mpha & - & - & TAY & - & $\mathrm{ARCO}$ & - & - & - & & Bioherm & 1 & $20-107 \mathrm{~m}$ \\
\hline \multicolumn{14}{|l|}{ Family Rhizangiidae } \\
\hline Astrangia solitaria (Lesueur, 1817) & Asol & GUA & PAL & TAY & MAG & - & MOR & DAR & - & & Wide & 1 & $10-154 \mathrm{~m}$ \\
\hline \multicolumn{14}{|l|}{ Family Schizocyathidae } \\
\hline Schizocyathus fissilis Pourtalès, 1874 & Sfis & - & - & TAY & MAG & $\mathrm{ARCO}$ & - & DAR & - & & Wide & $2(3)$ & $158-507 \mathrm{~m}$ \\
\hline \multicolumn{14}{|l|}{ Family Turbinoliidae } \\
\hline Sphenotrochus auritus Pourtalès, 1874 & Saur & - & - & TAY & - & - & - & - & - & • & NE & 1 & $10 \mathrm{~m}$ \\
\hline Sphenotrochus lindstroemi Cairns, 2000 & Slind & - & - & TAY & - & - & - & - & - & • & $\mathrm{NE}$ & 1 & $10 \mathrm{~m}$ \\
\hline \multicolumn{14}{|l|}{ Order Antipatharia } \\
\hline \multicolumn{14}{|l|}{ Family Antipathidae } \\
\hline Antipathes atlantica Gray, 1857 & Atla & - & PAL & - & - & - & - & - & - & • & Bioherm & 1 & $71.6 \mathrm{~m}$ \\
\hline Antipathes furcata Gray, 1857 & Afur & - & PAL & - & - & - & - & - & - & • & $\mathrm{NE}$ & 1 & $50-70 \mathrm{~m}$ \\
\hline Antipathes gracilis Gray, 1860 & Agra & - & PAL & TAY & - & $\mathrm{ARCO}$ & - & - & - & & Bioherm & 1 & $21-160 \mathrm{~m}$ \\
\hline Antipathes lenta Pourtalès, 1871 & Alen & GUA & PAL & TAY & - & - & - & - & - & & $\mathrm{NE}$ & 2 & $20-300 \mathrm{~m}$ \\
\hline Antipathes sp. & Atsp & - & - & TAY & - & - & - & - & - & - & $\mathrm{NE}$ & 2 & $200-494 \mathrm{~m}$ \\
\hline Cirripathes paucispina (Brook, 1889) & Cpau & - & - & TAY & - & - & - & - & - & • & $\mathrm{NE}$ & 1 & $150 \mathrm{~m}$ \\
\hline Stichopathes filiformis (Gray, 1860) & Sfil & - & PAL & - & - & - & - & - & - & - & $\mathrm{NE}$ & 1 & $150 \mathrm{~m}$ \\
\hline Stichopathes luetkeni (Brook, 1889) & Slue & - & PAL & - & - & $\mathrm{ARCO}$ & - & - & - & & Bioherm & 2 & $160-300 \mathrm{~m}$ \\
\hline Stichopathes occidentalis (Gray, 1860) & Socc & - & PAL & TAY & - & $\mathrm{ARCO}$ & - & - & - & & Bioherm & 1 & $70-160 \mathrm{~m}$ \\
\hline Stichopathes pourtalesi Brook, 1889 & Spou & GUA & PAL & TAY & - & - & - & - & - & & $\mathrm{NE}$ & 2 & $70-300 \mathrm{~m}$ \\
\hline Stichopathes sp. & Stich & GUA & PAL & TAY & MAG & - & - & - & - & & $\mathrm{NE}$ & 2 & $50-502 \mathrm{~m}$ \\
\hline \multicolumn{14}{|l|}{ Family Aphanipathidae } \\
\hline Aphanipathes salix (Pourtalès, 1880) & Asal & - & - & TAY & - & - & - & DAR & - & & Wide & 1 & $160-200 \mathrm{~m}$ \\
\hline Elatopathes abietina (Pourtalès, 1874) & Aabi & - & - & - & - & $\mathrm{ARCO}$ & - & - & - & - & Bioherm & 1 & $155-160 \mathrm{~m}$ \\
\hline Rhipidipathes colombiana (Opresko and Sánchez, 1997) & Aclm & - & - & TAY & - & - & - & - & - & • & NE & 3 & $296 \mathrm{~m}$ \\
\hline \multicolumn{14}{|l|}{ Family Myriopathidae } \\
\hline Tanacetipathes barbadensis (Brook, 1889) & Tbar & - & PAL & TAY & - & $\mathrm{ARCO}$ & - & - & - & & Bioherm & 1 & $50-160 \mathrm{~m}$ \\
\hline Tanacetipathes spinescens (Gray, 1860) & Aspi & - & - & - & - & $\mathrm{ARCO}$ & - & - & - & • & Bioherm & 1 & $160 \mathrm{~m}$ \\
\hline Tanacetipathes tanacetum (Pourtalès, 1880) & Ttan & GUA & - & - & - & - & - & - & - & - & $\mathrm{NE}$ & 3 & $305 \mathrm{~m}$ \\
\hline \multicolumn{14}{|l|}{ Family Stylopathidae } \\
\hline Stylopathes columnaris (Duchassaing, 1870) & Acol & - & PAL & TAY & - & $\mathrm{ARCO}$ & - & - & - & & Bioherm & 2 & $150-520 \mathrm{~m}$ \\
\hline Order Alcyonacea & & & & & & & & & & & & & \\
\hline
\end{tabular}


Table 2 (continued)

\begin{tabular}{|c|c|c|c|c|c|c|c|c|c|c|c|c|c|}
\hline Species & Code & GUA & PAL & TAY & MAG & $\mathrm{ARCO}$ & MOR & DAR & SAN & Ex. & GeoP & BatR & Depth \\
\hline Acanthogorgia aspera Pourtalès, 1867 & Aasp & - & PAL & TAY & - & ARCO & - & - & - & & Bioherm & 1 & $70-160 \mathrm{~m}$ \\
\hline Acanthogorgia schrammi Duchassaing and Michelotti, 1864 & Asch & - & PAL & TAY & - & - & - & - & - & & $\mathrm{NE}$ & 2 & $70-304 \mathrm{~m}$ \\
\hline Acanthogorgia sp. & Acsp & GUA & PAL & - & - & - & - & - & - & & $\mathrm{NE}$ & 1 & $50-50 \mathrm{~m}$ \\
\hline Muricella sp. & Muri & - & PAL & TAY & - & ARCO & - & - & - & & Bioherm & 2 & $20-504 \mathrm{~m}$ \\
\hline \multicolumn{14}{|l|}{ Family Alcyoniidae } \\
\hline Bellonella rubistella (Deichmann, 1936) & Brub & GUA & PAL & TAY & - & - & - & - & - & & $\mathrm{NE}$ & 1 & $70-152 \mathrm{~m}$ \\
\hline \multicolumn{14}{|l|}{ Family Anthothelidae } \\
\hline Diodogorgia nodulifera (Hargitt and Rogers, 1901) & Dnod & GUA & PAL & TAY & - & - & - & DAR & - & & Wide & 2 & $10-300 \mathrm{~m}$ \\
\hline \multicolumn{14}{|l|}{ Family Chrysogorgiidae } \\
\hline Chrysogorgia desbonni Duchassaing and Michelotti, 1864 & Cdes & - & - & - & - & ARCO & - & - & - & • & SW & 3 & $296-296 \mathrm{~m}$ \\
\hline Chrysogorgia elegans Verrill, 1883 & Cele & GUA & PAL & TAY & - & ARCO & - & - & - & & Wide & 3 & $484-510 \mathrm{~m}$ \\
\hline Chrysogorgia sp. & Chry & - & - & - & MAG & $\mathrm{ARCO}$ & - & - & - & & Wide & 2 & $70.5-475 \mathrm{~m}$ \\
\hline Chrysogorgia thyrsiformis Deichmann, 1936 & Cthy & - & - & - & - & ARCO & - & - & - & - & Bioherm & 1 & $160-160 \mathrm{~m}$ \\
\hline Trichogorgia lyra Bayer and Muzik, 1976 & Tlyr & GUA & PAL & TAY & MAG & ARCO & - & DAR & - & & Wide & 1 & $20-150 \mathrm{~m}$ \\
\hline \multicolumn{14}{|l|}{ Family Clavulariidae } \\
\hline Carijoa riisei Duchassaing and Michelotti, $1860^{*}$ & Crii & GUA & PAL & TAY & MAG & - & - & - & - & & NE & 2 & $21.4-500 \mathrm{~m}$ \\
\hline \multicolumn{14}{|l|}{ Family Ellisellidae } \\
\hline Ctenocella sp.1 *a & Cteno & GUA & PAL & - & - & - & - & - & - & & $\mathrm{NE}$ & 1 & $20-152 \mathrm{~m}$ \\
\hline Ellisella barbadensis (Duchassaing and Michelotti, 1864)* & Ebar & GUA & - & - & - & - & - & - & - & • & $\mathrm{NE}$ & 1 & $50 \mathrm{~m}$ \\
\hline Nicella guadalupensis (Duchassaing and Michelotti, 1860) & Ngua & - & - & - & - & $\mathrm{ARCO}$ & - & - & - & - & SW & 1 & $107-160 \mathrm{~m}$ \\
\hline Nicella $s p$ & Nicel & - & - & TAY & - & ARCO & - & - & - & & Bioherm & 1 & $107-200 \mathrm{~m}$ \\
\hline Riisea paniculata Duchassaing and Michelotti, 1860 & Rpan & - & - & TAY & - & ARCO & - & - & - & & Bioherm & 1 & $160-200 \mathrm{~m}$ \\
\hline 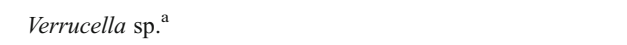 & Verru & GUA & PAL & TAY & - & $\mathrm{ARCO}$ & - & - & - & & Wide & 1 & $50-200 \mathrm{~m}$ \\
\hline Viminella $\mathrm{sp}$. & Vimin & GUA & PAL & TAY & - & ARCO & - & DAR & - & & Wide & 2 & $20-300 \mathrm{~m}$ \\
\hline \multicolumn{14}{|l|}{ Family Gorgoniidae } \\
\hline Leptogorgia cardinalis (Bayer, 1961) & Lcar & GUA & PAL & - & - & - & - & - & - & & NE & 2 & $50-498 \mathrm{~m}$ \\
\hline Leptogorgia medusa Bayer, $1952^{*}$ & Lmed & - & PAL & - & - & - & - & - & - & • & $\mathrm{NE}$ & 1 & $70 \mathrm{~m}$ \\
\hline Leptogorgia punicea (Milne Edwards and Haime, 1857) & Lpun & GUA & - & - & MAG & - & - & - & - & & Wide & 1 & $10-20.9 \mathrm{~m}$ \\
\hline Leptogorgia setacea Pallas, $1766^{*}$ & Lset & GUA & PAL & TAY & - & - & - & DAR & - & & Wide & 1 & $10-152 \mathrm{~m}$ \\
\hline Leptogorgia sp. $1^{*}$ & Lepto & GUA & - & - & - & - & - & - & - & • & $\mathrm{NE}$ & 1 & $50 \mathrm{~m}$ \\
\hline Leptogorgia sp. $2^{*}$ & Lopho & GUA & PAL & - & MAG & - & - & - & - & & Wide & 2 & $10-475 \mathrm{~m}$ \\
\hline Pterogorgia sp. $^{+}$ & Ptero & GUA & - & - & - & - & - & - & - & • & NE & 1 & $10 \mathrm{~m}$ \\
\hline Tobagogorgia hardyi Sánchez and Acosta de Sánchez, 2004 & Thar & GUA & PAL & TAY & - & - & - & - & - & & $\mathrm{NE}$ & 1 & $26.6-76 \mathrm{~m}$ \\
\hline \multicolumn{14}{|l|}{ Family Keroeididae } \\
\hline Thelogorgia vossi Bayer, 1991 & Tvos & - & - & TAY & - & - & - & - & - & - & Bioherm & 1 & $200 \mathrm{~m}$ \\
\hline \multicolumn{14}{|l|}{ Family Nephtheidae } \\
\hline Stereonephthya portoricensis (Hargitt, 1901) & Spor & - & PAL & TAY & - & ARCO & - & - & - & & Bioherm & 1 & $20-200 \mathrm{~m}$ \\
\hline \multicolumn{14}{|l|}{ Family Nidaliidae } \\
\hline Nidalia deichmannae Utinomi, 1954 & Ndei & - & - & - & - & $\mathrm{ARCO}$ & - & - & - & • & SW & 1 & $107 \mathrm{~m}$ \\
\hline Nidalia dissidens Verseveldt and Bayer, 1988 & Ndis & - & - & TAY & - & - & - & - & - & • & Bioherm & 1 & $200 \mathrm{~m}$ \\
\hline Nidalia occidentalis Gray, 1835 & Nocc & - & - & - & - & ARCO & - & - & - & - & SW & 1 & $107-160 \mathrm{~m}$ \\
\hline Nidalia rubripunctata Verseveldt and Bayer, 1988 & Nrub & GUA & PAL & TAY & - & $\mathrm{ARCO}$ & - & - & - & & Wide & 1 & $20-155 \mathrm{~m}$ \\
\hline Nidalia sp. & Nidal & GUA & PAL & - & - & - & - & - & - & & $\mathrm{NE}$ & 1 & $50-70 \mathrm{~m}$ \\
\hline Siphonogorgia agassizii (Deichmann, 1936) & Saga & - & - & - & - & ARCO & - & - & - & - & SW & 1 & $107 \mathrm{~m}$ \\
\hline \multicolumn{14}{|l|}{ Family Plexauridae } \\
\hline Astrogorgia sp. & Amsp & GUA & - & TAY & - & - & - & - & - & & $\mathrm{NE}$ & 1 & $73-152 \mathrm{~m}$ \\
\hline Eunicea sp. $^{+}$ & Eunic & GUA & - & - & - & - & - & - & - & - & $\mathrm{NE}$ & 1 & $10 \mathrm{~m}$ \\
\hline Hypnogorgia pendula Duchassaing and Michelotti, 1864 & Hpen & - & - & - & - & $\mathrm{ARCO}$ & - & - & - & • & Bioherm & 1 & $160 \mathrm{~m}$ \\
\hline Lytreia plana (Deichmann, 1936) & Lplan & - & - & - & - & $\mathrm{ARCO}$ & - & - & - & • & Bioherm & 1 & $98 \mathrm{~m}$ \\
\hline Muricea elongata (Lamouroux, 1821) ${ }^{+}$ & Melo & - & - & TAY & - & - & - & - & - & - & $\mathrm{NE}$ & 1 & $35 \mathrm{~m}$ \\
\hline Paracis sp. & Parsp & GUA & PAL & - & - & ARCO & - & - & - & & Wide & 1 & $50-160 \mathrm{~m}$ \\
\hline Placogorgia atlantica Wright and Studer, 1889 & Patl & - & - & TAY & - & - & - & - & - & - & $\mathrm{NE}$ & 1 & $72.3-200 \mathrm{~m}$ \\
\hline Placogorgia tenuis (Verrill, 1883) & Pten & - & - & TAY & - & $\mathrm{ARCO}$ & - & - & - & & Bioherm & 1 & $155-200 \mathrm{~m}$ \\
\hline Scleracis guadaloupensis Duchassaing and Michelotti, 1860 & Sgua & - & - & TAY & - & ARCO & - & - & - & & Bioherm & 1 & $113-200 \mathrm{~m}$ \\
\hline Scleracis pumila Reiss, 1919 & Spum & - & - & - & - & ARCO & - & - & - & • & Bioherm & 1 & $113-160 \mathrm{~m}$ \\
\hline Scleracis sp. & Scler & GUA & PAL & - & - & ARCO & - & - & - & & Wide & 1 & $50-127 \mathrm{~m}$ \\
\hline
\end{tabular}


Table 2 (continued)

\begin{tabular}{|c|c|c|c|c|c|c|c|c|c|c|c|c|c|}
\hline Species & Code & GUA & PAL & TAY & MAG & ARCO & MOR & DAR & SAN & Ex. & GeoP & BatR & Depth \\
\hline Swiftia exserta Duchassaing and Michelotti, 1864 & Sexe & - & PAL & - & - & - & - & DAR & - & & Wide & 1 & $20-70 \mathrm{~m}$ \\
\hline Thesea bicolor Deichamnn, 1936 & Tbic & - & PAL & - & - & - & - & - & - & • & $\mathrm{NE}$ & 1 & $70 \mathrm{~m}$ \\
\hline Thesea nutans (Duchassaing and Michelotti, 1864) & Cnut & - & - & - & - & ARCO & - & - & - & • & Bioherm & 1 & $98-160 \mathrm{~m}$ \\
\hline Thesea parviflora Deichmann, 1936 & Tpar & GUA & PAL & TAY & - & - & - & - & - & & $\mathrm{NE}$ & 2 & $20-300 \mathrm{~m}$ \\
\hline Thesea solitaria Pourtalès, 1868 & Tsol & - & - & TAY & - & - & - & - & - & • & Bioherm & 1 & $200 \mathrm{~m}$ \\
\hline Thesea sp. & These & GUA & PAL & TAY & - & - & - & - & - & & $\mathrm{NE}$ & 1 & $20-154 \mathrm{~m}$ \\
\hline Villogorgia nigrescens Duchassaing and Michelotti, 1860 & Vnig & - & - & TAY & - & - & - & - & - & • & Bioherm & 1 & $200 \mathrm{~m}$ \\
\hline Villogorgia sp. & Villog & - & PAL & - & - & - & - & - & - & - & $\mathrm{NE}$ & 3 & $300 \mathrm{~m}$ \\
\hline \multicolumn{14}{|l|}{ Family Primnoidae } \\
\hline Callogorgia sp. & Callo & - & - & TAY & - & - & - & - & - & • & Bioherm & 1 & $200 \mathrm{~m}$ \\
\hline \multicolumn{14}{|l|}{ Order Pennatulacea } \\
\hline \multicolumn{14}{|l|}{ Family Kophobelemnidae } \\
\hline Sclerobelemnon theseus Bayer, 1959 & Sthe & GUA & PAL & TAY & MAG & ARCO & - & - & - & & Wide & 1 & $20-153 \mathrm{~m}$ \\
\hline \multicolumn{14}{|l|}{ Family Renillidae } \\
\hline Renilla muelleri Kölliker, 1872 & Rmue & GUA & PAL & TAY & MAG & - & - & - & - & & $\mathrm{NE}$ & 1 & $10-76 \mathrm{~m}$ \\
\hline Renilla reniformis (Pallas, 1766) & Rren & - & PAL & - & MAG & - & - & DAR & - & & Wide & 1 & $10-70.4 \mathrm{~m}$ \\
\hline \multicolumn{14}{|l|}{ Family Virgulariidae } \\
\hline Acanthoptilum sp. & Almsp & GUA & - & TAY & - & ARCO & - & - & - & & Wide & 1 & $50-151 \mathrm{~m}$ \\
\hline Stylatula diadema Bayer, $1959^{*}$ & Stdia & - & - & - & - & ARCO & - & - & - & • & SW & 1 & $20 \mathrm{~m}$ \\
\hline
\end{tabular}

${ }^{a}$ Specimens were identified as belonging to the genera Ctenocella and Verrucella according to Bayer and Grasshoff (1995)

\section{References}

Adjeroud M (1997) Factors influencing spatial patterns on coral reefs around Moorea, French Polynesia. Mar Ecol Prog Ser 159:105-119

Alonso D, Ramírez LF, Segura-Quintero C, Castillo-Torres P, Walschburger T, Arango N (2008a) Hacia la construcción de un subsistema nacional de áreas marinas protegidas en Colombia. Instituto de Investigaciones Marinas y Costeras-INVEMAR, UAESPNN, TNC, Santa Marta

Alonso D, Segura-Quintero C, Castillo-Torres P, Gerhantz-Muro J (2008b) Avances en el diseño de una red de áreas marinas protegidas: estrategia de conservación para el norte del Caribe continental colombiano. Bol Invest Mar Cost 37:129-156

Andrade CA, Barton ED (2000) Eddy development and motion in the Caribbean Sea. J Geophys Res 105:26191-26201

Andrade CA, Barton ED (2005) The Guajira upwelling system. Cont Shelf Res 25:1003-1022

Andrade CA, Barton ED, Mooers CNK (2003) Evidence for an eastward flow along the Central and South American Caribbean Coast. J Geophys Res 108:1-11

Ardila N, Navas GR, Reyes J (2002) Libro rojo de invertebrados marinos de Colombia. Serie Libros Rojos de Especies Amenazadas de Colombia. Instituto de Investigación de Recursos Biológicos Alexander von Humboldt y Ministerio del Medio Ambiente. Bogotá

Bayer FM (1961) The shallow water Octocorallia of the West Indian region. Stud Fauna Curaçao 12:1-373

Bayer FM, Grasshoff M (1995) Two new species of the gorgonacean genus Ctenocella (Coelenterata: Anthozoa, Octocorallia) from deep reefs in the western Atlantic. Bull Mar Sci 56:625-652

Bayer FM, Grasshoff M, Verseveldt J (1983) An illustrated trilingual glossary of morphological and anatomical terms applied to Octocorallia. Brill, Leiden

Benavides-Serrato M, Borrero-Pérez GH, Diaz-Sanchez CM (2011) Equinodermos del caribe colombiano I: crinoidea, asteroidea y ophiuoridea. INVEMAR Ser Publ Esp 22:1-384
Bongaerts P, Ridgway T, Sampayo EM, Hoegh-Guldberg O (2010) Assessing the 'deep reef refugia' hypothesis: focus on Caribbean reefs. Coral Reefs 29:309-327

Borrero-Pérez GH, Benavides-Serrato M (2004) New record of Ophiosyzygus disacanthus Clark, 1911 (Echinodermata: Ophiuroidea: Ophiomyxidae) in the Caribbean Sea. Proc Biol Soc Wash 117:541-544

Borrero-Pérez GH, Benavides-Serrato M, Solano O, Navas G (2002a) Equinoideos (Echinodermata: Echinoidea) colectados en la franja superior del talud continental del Caribe colombiano. Bol Inst Inv Mar Cost 31:133-166

Borrero-Pérez GH, Solano OD, Benavides M (2002b) Lista revisada de los erizos (Echinodermata: Echinoidea) del mar Caribe colombiano. Biota Colomb 3:137-144

Botero L (1987) Zonación de octocorales gorgonáceos en el área de Santa Marta y Parque Nacional Natural Tayrona, Costa Caribe colombiana. An Inst Inv Mar Punta Betín 17:61-80

Bottjer DJ, Jablonski D (1988) Paleoenvironmental patterns in the evolution of post-Paleozoic benthic marine invertebrates. Palaios 3:540-560

Brook G (1889) The Voyage of H.M.S. Challenger. Zoology. Report on the Antipatharia collected by H.M.S. Challenger during the years 1873-76. Zoology 32(80):1-222, pls 1-15

Brown JH, Lomolino MV (1998) Biogeography, 2nd edn. Sinauer, Sunderland

Buddemeier RW, Fautin DG (1996) Saturation state and the evolution and biogeography of symbiotic calcification. Bull Inst Oceánogr Monaco 14:23-32

Buddemeier RW, Smith SV (1999) Coral adaptation and acclimatization: a most ingenious paradox. Am Zool 39:1-9

Cairns SD (1979) The deep-water Scleractinia of the Caribbean Sea and adjacent waters. Stud Fauna Curaçao Caribb Is 180:1-341

Cairns SD (1999) Cnidaria Anthozoa: deep-water azooxanthellate Scleractinia from Vanuatu, and Wallis and Futuna Islands. Mem Mus Natl Hist 180:31-167

Cairns SD (2000) A revision of the shallow-water azooxanthellate Scleractinia of the Western Atlantic. Stud Nat Hist Caribb Reg $75: 1-231$ 
Cairns SD (2007) Deep-water corals: an overview with special reference to diversity and distribution of deep-water scleractinian corals. Bull Mar Sci 81:311-322

Cairns SD, Kitahara MV (2012) An illustrated key to the genera and subgenera of the Recent azooxanthellate scleractinia (Cnidaria: Anthozoa), with an attached glossary. ZooKeys 227:1-47

Cairns SD, Zibrowius H (1997) Cnidaria Anthozoa: Azooxanthellate Scleractinia from the Philippines and Indonesian regions. Mem Mus Natl Hist 172:27-243

Cairns SD, Hoeksema BW, van der Land J (1999) Appendix: list of extant stony corals. Atoll Res Bull 459:13-46

Campos NH, Navas G, Bermúdez A, Cruz A (2004) Los crustáceos decápodos de la franja superior del talud continental (300-500 m) del Mar Caribe Colombiano. Monogr Fauna Colombia. 2. Instituto de Ciencias Naturales, Universidad Nacional de Colombia, Bogotá

Carpenter KE, Abrar M, Aeby G et al (2008) One-third of reef-building corals face elevated extinction risk from climate change and local impacts. Science 321:560-563

Chacón-Gómez IC, Santodomingo N, Reyes J (2008) First record of Tobagogorgia hardyi (Octocorallia: Gorgoniidae) from the Colombian Caribbean. Bol Inv Mar Cost 37:209-214

Chacón-Gómez IC, Santodomingo N, Reyes J, Andrade Sossa CE (2010) Chrysogorgiidae (Octocorallia) recolectados durante las expediciones Macrofauna I y II en el Caribe colombiano. Bol Inv Mar Cost 39:427-445

Chacón-Gómez IC, Reyes J, Santodomingo N (2012) Deep-water octocorals (Cnidaria: Anthozoa) collected from the Colombian Caribbean during the Macrofauna explorations 1998-2002. Bol Inv Mar Cost 41:193-211

Clarke KR, Gorley RN (2006) PRIMER v6: user manual/tutorial. PRIMER-E. Plymouth Marine Laboratory, Plymouth

Collins L, Budd AF, Coates AG (1996) Earliest evolution associated with closure of the Tropical American Seaway. Proc Natl Acad Sci USA 93:6069-6072

Cruz N, Bermúdez A, Campos NH, Navas GR (2002) Los camarones de la Familia Crangonidae del talud continental entre 200 y $500 \mathrm{~m}$ del Mar Caribe colombiano. Bol Inv Mar Cost 31:183-203

Dawson JP (2002) Biogeography of azooxanthellate corals in the Caribbean and surrounding areas. Coral Reefs 21:27-40

Dayton PK (1998) Reversal of the burden of proof in fisheries management. Science 279:821-822

Deichman E (1936) The Alcyonaria of the western part of the Atlantic Ocean. Mem Mus Comp Zool Harvard Univ 53:1-317

Díaz JM, Acero A (2003) Marine biodiversity in Colombia: achievements, status of knowledge, and challenges. Gayana 67:261-274

Díaz JM, Barrios LM, Cendales MH, Garzón-Ferreira J, Geister J, López-Victoria M, Ospina GH, Parra-Valencia F, Pinzón J, Vargas-Angel B, Zapata FA, Zea S (2000) Áreas coralinas de Colombia. INVEMAR Ser Publ Esp 5:1-176

Durham JW, Barnard JL (1952) Stony corals of the eastern Pacific collected by the Velero III and Velero IV. Allan Hancock Pacific Expeditions 1(16): 1-110

Fabricius K, Aldersdale P (2001) Soft corals and sea fans: acomprehensive guide to the tropical shallow water genera of the centralwest Pacific, the Indian Ocean and the Red Sea. Australian Institute of Marine Science, Townsville

Flórez-Romero P, Montoya-Cadavid E, Reyes J, Santodomingo N (2007) Briozoos cheilostomados del Caribe Colombiano. Bol Inv Mar Cost 36:229-250

Friedlander A, Sladek-Nowlis J, Sánchez JA, Appeldoorn R, Usseglio P, Mccormick C, Bejarano S, Mitchell-Chui A (2003) Designing effective marine protected areas in Seaflower Biosphere Reserve, Colombia, based on biological and sociological information. Conserv Biol 17:1769-1784

García CB, Perez D, Duarte LO, Manjarres L (2008) Experimental results with a reducing device for juvenile fishes in a tropical shrimp fishery: impact on the invertebrate bycatch. Pan-American J Aqua Sci 3:275-281

Gaston KJ (2000) Global patterns in biodiversity. Nature 405:220-228

Gering JC, Crist TO, Veech JA (2003) Additive partitioning of species diversity across multiple spatial scales: implications for regional conservation of biodiversity. Conserv Biol 17:488-499

Gracia A, Ardila NE, Díaz JM (2002) Cefalópodos (Mollusca: Cephalopoda) del talud superior del Caribe colombiano. Bol Inst Inv Mar Cost 31:219-238

Gracia A, Ardila NE, Díaz JM (2004) Gastropods collected along the continental slope of the Colombian Caribean during the INVEMAR-macrofauna campains (1998-2001). Iberus 22:43-75

Gracia A, Rangel-Buitrago N, Sellanes J (2012) Methane seep molluscs from the Sinu-San Jacinto fold belt in the Caribbean Sea of Colombia. J Mar Biol Ass UK 92:1367-1377

Grassle JF (1991) Deep-sea benthic biodiversity. Bioscience 41:464 469

Guinotte JM, Orr J, Cairns S, Freiwald A, Morgan L, George R (2006) Will human induced changes in seawater chemistry alter the distribution of deep-sea scleractinian corals? Front Ecol Environ 4:141-146

Herazo D, Torres A, Olsen E (2006) Análisis de la composición y abundancia de la ictiofauna presente en la pesca del camarón rosado (Penaeus notialis) en el Golfo de Morrosquillo, Caribe Colombiano. Rev MVZ Cordoba 11(Suppl 1):47-61

Hoeksema BW (2007) Delineation of the Indo-Malayan centre of maximum marine biodiversity: the Coral Triangle. In: Renema W (ed) Biogeography, time and place: distributions, barriers and islands. Springer, Dordrecht, pp 117-178

Hoeksema BW, Best MB (1991) New observations on scleractinian corals from Indonesia: 2. Sipunculan-associated species belonging to the genera Heterocyathus and Heteropsammia. Zool Meded $65: 221-245$

Hoeksema BW, van Ofwegen LP (2008) Oceanic distribution ranges and conservation status of extant soft and hard reef coral genera. In: Leewis RJ, Janse M (eds) Advances in coral husbandry in public Aquariums. Burger's Zoo, Arnhem, pp 427-438

Hoeksema BW, van der Land J, van der Meij SET, van Ofwegen LP, Reijnen BT, van Soest RWM, de Voogd NJ (2011) Unforeseen importance of historical collections as baselines to determine biotic change of coral reefs: the Saba Bank case. Mar Ecol 32:135-141

Houston M (1985) Patterns of species diversity in relation to depth at Discovery Bay, Jamaica. Bull Mar Sci 3:928-935

INVEMAR (2000) Programa Nacional de Investigaciones en Biodiversidad Marina y Costera-PNIBM. INVEMAR-FONADE, MMA, Santa Marta

Janiszewska K, Stolarski J, Benzerara K, Meibom A, Mazur M, Kitahara M, Cairns SD (2011) A unique skeletal microstructure of the deepsea micrabaciid scleractinian corals. J Morphol 272:191-203

Kahng SE, Maragos JE (2006) The deepest, zooxanthellate scleractinian corals in the world? Coral Reefs 25:254

Kahng SE, Garcia-Sais JR, Spalding HL, Brokovich E, Wagner D, Weil E, Hinderstein L, Toonen RJ (2010) Community ecology of mesophotic coral reef ecosystems. Coral Reefs 29:255-275

Kitahara MV (2007) Species richness and distribution of azooxanthellate Scleractinia in Brazil. Bull Mar Sci 81:497-518

Knowlton N, Weigt LA (1998) New dates and new rates for divergence across the Isthmus of Panama. Proc R Soc Lond B 265:2257-2263

Lakewood CO (1999) Boundary development on the outer continental shelf. OCS Report MMS 99-0006. US Department of the Interior Minerals Management Service Mapping and Boundary Branch

Lattig P, Cairns S (2000) A new species of Tethocyathus (Cnidaria: Anthozoa: Scleractinia: Caryophylliidae), a trans-isthmian azooxanthellate species. Proc Biol Soc Wash 113:590-595

Lattig P, Reyes J (2001) Nueve primeros registros de corales azooxanthellados (Anthozoa: Scleractinia) del Caribe colombiano (200$500 \mathrm{~m})$. Bol Inv Mar Cost 30:19-38 
Lessios HA (2008) The great American schism: divergence of marine organisms after the rise of the Central American isthmus. Annu Rev Ecol Evol Syst 39:63-91

Lindner A, Cairns SD, Cunningham CW (2008) From offshore to onshore: multiple origins of shallow-water corals from deep-sea ancestors. PLoS ONE 3(6):e2429

Lomolino MV (2004) Conservation biogeography. In: Lomolino MV, Heaney LR (eds) Frontiers of biogeography: new directions in the geography of nature. Sinauer, Sunderland, pp 293-296

Ludwig D, Hilborn R, Walters C (1993) Uncertainty, resource exploitation, and conservation: lessons from history. Science 260:17-18

Matsumoto AK, Iwase F, Imahara Y, Namikawa H (2007) Bathymetric distribution and biodiversity of cold-water octocorals (Coelenterata: Octocorallia) in Sagami Bay and adjacent waters of Japan. Bull Mar Sci 81(Suppl 1):231-251

MAVDT (2005) Resolución 0679 del 31 de mayo de 2005, por medio de la cual se declara el Área Marina Protegida de los Archipiélagos del Rosario y de San Bernardo, se adopta su zonificación interna y se dictan otras disposiciones. MAVDT, Bogotá

Miloslavich P, Díaz JM, Klein E et al (2010) Marine biodiversity in the Caribbean: regional estimates and distribution patterns. PLoS ONE 5(8):e11916

Mittermeier RA, Gil PR, Mittermeier CG (1997) Megadiversity: Earth's biologically wealthiest nations. Conservation International, Washington DC

Mok H, Saavedra-Díaz LM, Acero A (2001) Two new species of Eptatretus and Quadratus (Myxinidae, Myxiniformes) from the Caribbean coast of Colombia. Copeia 4:1026-1033

Opresko DM (2001) Revision of the Antipatharia (Cnidaria: Anthozoa). Part I. Establishment of a new family, Myriopathidae. Zool Meded 75:147-174

Opresko DM (2002) Revision of the Antipatharia (Cnidaria: Anthozoa). Part II. Schizopathidae. Zool Meded 76:411-442

Opresko DM (2003) Revision of the Antipatharia (Cnidaria: Anthozoa). Part III. Cladopathidae. Zool Meded 77:495-536

Opresko DM (2004) Revision of the Antipatharia (Cnidaria: Anthozoa). Part IV. Establishment of a new family, Aphanipathidae. Zool Meded 78:209-240

Opresko DM (2006) Revision of the Antipatharia (Cnidaria: Anthozoa). Part V. Establishment of a new family, Stylopathidae. Zool Meded 80:109-138

Opresko DM, Sánchez JA (1997) A new species of antipatharian coral (Cnidaria: Anthozoa) from the Caribbean coast of Colombia. Caribb J Sci 33:75-81

Opresko DM, Sánchez JA (2005) Caribbean shallow-water black corals (Cnidaria: Anthozoa: Antipatharia). Caribb J Sci 41:492-507

Pandolfi JM, Jackson JBC, Baron N, Bradbury RH, Guzman HM, Hughes TP, Kappel CV, Micheli F, Ogden JC, Possingham HP, Sala E (2005) Are U.S. coral reefs on the slippery slope to slime? Science 307:1725-1726

Restrepo JD, Zapata P, Díaz JM, Garzón-Ferreira J, García CB (2006) Fluvial fluxes into the Caribbean Sea and their impact on coastal ecosystems: the Magdalena river, Colombia. Glob Planet Change 50:33-49

Reyes J (2000) Lista de los Corales (Cnidaria: Anthozoa: Scleractinia) de Colombia. Biota Colomb 1:164-176

Reyes J, Santodomingo N (2002) Manual de identificación CITES de invertebrados marinos de Colombia. Serie manuales de identificación CITES de Colombia. INVEMAR, Santa Marta

Reyes J, Santodomingo N, Gracia A, Borrero G, Navas G, MejíaLadino L, Bermúdez A, Benavides M (2005) Southern Caribbean azooxanthellate coral communities off Colombia. In: Freiwald A, Roberts JM (eds) Cold-water corals and ecosystems. Springer, Berlin, pp 309-330

Reyes J, Santodomingo N, Cairns S (2009) Caryophylliidae (Scleractinia) from the Colombian Caribbean. Zootaxa 2262:1-39
Reyes J, Santodomingo N, Flórez P (2010) Corales escleractinios de Colombia. INVEMAR Ser Publ Esp 14:1-246

Reyes-Bonilla H, Cruz-Piñón G (2000) Biogeography of the ahermatypic corals (Scleractinia) of the Mexican Pacific. Cienc Mar 26:511-531

Roa-Varón A, Saavedra-Díaz L, Acero A, Mejía LS, Navas G (2003) Nuevos registros de peces óseos para el Caribe colombiano de los órdenes Beryciformes, Zeiformes, Perciformes y Tetraodontiformes. Bol Inst Inv Mar Cost 32:3-24

Roberts JM, Wheeler AJ, Freiwald A (2006) Reefs of the deep: the biology and geology of cold-water coral ecosystems. Science 213:543-547

Roberts JM, Wheeler AJ, Freiwald A, Cairns S (2009) Cold-water corals: The biology and geology of deep-sea coral habitats. Cambridge University Press, Cambridge

Saavedra-Díaz L, Acero A, Navas A (2000) Lenguados de la familia Paralichthyidae (Pisces: Pleuronectiformes) conocidos del Caribe colombiano. Rev Acad Colomb Cienc Exact Fís Nat 24:295-310

Sánchez JA (1994) Presencia de los Octocorales Stylatula diadema Bayer (Pennatulacea) y Carijoa riisei (Duchassaing y Michelotti) /Telestacea) en la costa Caribe colombiana. An Inst Inv Mar Punta Betín 23:137-147

Sánchez JA (1995) Benthic communities and geomorphology of the Tesoro Island reefs, Colombian Caribbean. An Inst Inv Mar Punta Betín 24:55-77

Sánchez JA (1998) Sistemática filogenética del género Eunicea Lamoroux, 1816 (Octocorallia: Gorgonacea: Plexauridae) con aspectos sobre la historia natural de algunas especies en el Caribe colombiano. MSc Thesis Universidad Nacional de Colombia, Bogotá

Sánchez JA (1999) Black coral-octocoral distribution patterns on Imelda Bank, a deep-water reef, Colombia, Caribbean Sea. Bull Mar Sci 65:215-225

Sánchez JA (2001) Systematics of the southwestern Caribbean Muriceopsis Aurivillius (Cnidaria: Octocorallia), with the description of a new species. Bull Biol Soc Wash 10:160-180

Sánchez JA, Wirshing H (2005) A field key to the identification of tropical western Atlantic zooxanthellate octocorals (Octocorallia: Cnidaria). Caribb J Sci 41:508-522

Sánchez JA, Díaz JM, Zea S (1997) Gorgonian communities in two contrasting environments on oceanic atolls of the southwestern Caribbean. Bull Mar Sci 61:453-465

Sánchez JA, Zea S, Díaz JM (1998) Patterns of octocoral and black coral distribution in the oceanic barrier reef-complex of Providencia Island, Southwestern Caribbean. Caribb J Sci 34:250-264

Santodomingo N, Reyes J, Gracia A, Martínez A, Ojeda G, García C (2007) Azooxanthellate Madracis coral communities off San Bernardo Islands (Colombian Caribbean). Bull Mar Sci 81(Suppl 1):273-287

Spalding MD, Fox HE, Allen GR, Davidson N, Ferdaña ZA, Finlayson M, Halpern BS, Jorge MA, Lombana A, Lourie SA, Martin KD, McManus E, Molnar J, Recchia CA, Robertson J (2007) Marine ecoregions of the world: a bioregionalization of coastal and shelf areas. Bioscience 57:573-583

Stewart R (2008) Introduction to physical oceanography. Department of Oceanography, Texas A\&M University

Stolarski J, Zibrowius H, Löser H (2001) Antiquity of the scleractiniansipunculan symbiosis. Acta Palaeontol Pol 46:309-330

Veron JEN (2000) Corals of the world. Australian Institute of Marine Science, Townsville

Verseveldt J, Bayer FM (1988) Revision of the genera Bellonella, Eleutherobia, Nidalia and Nidaliopsis (Octocorallia: Alcyoniidae and Nidaliidae), with descriptions of two new genera. Zool Verh 245:1-131

Viaña, J, Medina A, Barrios M, Manjares L (2002) Evaluación de la ictiofauna demersal extraída por la pesquería industrial de arrastre en el área norte del Caribe colombiano (Enero 2000-Junio 2001). 
In: INPA-COLCIENCIAS. Informe técnico final Proyecto Evaluación de las pesquerías demersales del área norte del Caribe colombiano y parámetros ecológicos, biológico-pesqueros y poblacionales del recurso pargo (Código: 3135-09-550-98)

von Prahl H, Erhardt H (1985) Colombia, corales y Arrecifes coralinos. FEN-Colombia, Editorial Presencia, Bogotá

von Prahl H, Erhardt H (1989) Lista anotada de corales ahermatípicos de Colombia. Memorias del VI Seminario Nacional de Ciencias del Mar, pp 539-556

Werding B, Sánchez H (1989) The coral formations and their distributional pattern along a wave exposure gradient in the area of Santa Marta, Colombia. Medio Ambiente 10:61-68
Williams GC (1995) Living genera of sea pens (Coelenterata: Octocorallia: Pennatulacea): illustrated key and synopses. Zool J Linn Soc Lond 113:93-140

Williams GC (1999) Index Pennatulacea: annotated bibliography and indexes of the Sea Pens (Coelenterata: Octocorallia) of the World 1469-1999. Proc Calif Acad Sci 51:19-103

Zibrowius H (1980) Les Scléractiniaries de la Mediterranée et de l'Atlantique nord-oriental. Mém Inst Océanogr Monaco 11:1248, $107 \mathrm{pls}$

Zibrowius H (1998) A new type of symbiosis: Heterocyathus japonicus (Cnidaria: Scleractinia) living on Fissidentalium vernedei (Mollusca: Scaphopoda). Zool Verh 323:319-334 